\title{
Developing a Multidimensional Checklist for Evaluating Language-Learning Websites Coherent with the Communicative Approach: A Path for the Knowing-How-To-Do Enhancement
}

\author{
Sthephanny Moncada Linares and Andrea Carolina Díaz Romero \\ Universidad La Gran Colombia, Colegio Cristo Rey, \\ Bogotá, Colombia
}

\author{
sthephanny.moncada@ugc.edu.co; \\ carolinaromero20141@outlook.com
}

[NOTE: A shorter version of this paper was presented at the Eighth edition of the International Conference ICT for Language Learning (Florence, Italy, 2015).]

\begin{abstract}
As a result of the rapid development of Information and Communication Technology (ICT) and the growing interest in Internet-based tools for language classroom, it has become a pressing need for educators to locate, evaluate and select the most appropriate language-learning digital resources that foster more communicative and meaningful learning processes. Hence, this paper describes a mixed research project that, on the first hand, aimed at proposing a Checklist for evaluating language websites built on the principles of the Communicative Approach, and on the second hand, sought to strengthen the teachers' Knowing-how-to-do skill as part of their digital competence. To achieve these goals, a four-phase research procedure was followed that included reviewing relevant literature and administering qualitative and quantitative research methods to participants (i.e., language teachers, an expert in the Computer-Assisted Language Learning (CALL) field and a college professor) in order to gain insights into problematic issues and, thereafter, to contribute to the creation and validation of the Checklist model and the Study Guide. The findings revealed that: (a) evaluating language websites leads to the enhancement of the teachers' practical skills and their knowledge of the technological language; and (b) having an assessment instrument allows educators to choose the materials that best meet their communicative teaching purposes.
\end{abstract}

Keywords: Language-learning website, communicative approach, CALL evaluation, checklist, digital competence, knowing-how-to-do skill

Material published as part of this publication, either on-line or in print, is copyrighted by the Informing Science Institute. Permission to make digital or paper copy of part or all of these works for personal or classroom use is granted without fee provided that the copies are not made or distributed for profit or commercial advantage AND that copies 1) bear this notice in full and 2) give the full citation on the first page. It is permissible to abstract these works so long as credit is given. To copy in all other cases or to republish or to post on a server or to redistribute to lists requires specific permission and payment of a fee. Contact Publisher@InformingScience.org to request redistribution permission.

\section{Introduction}

The great influence of the Internet on all areas of society (e.g., politics, economy, leisure, relationships, education) has managed to redefine and extend the boundaries of interpersonal communication, entertainment, information transfer, teaching practices, and so forth. There- 
by, in the education realm, especially in the language teaching and learning context, the integration of the Internet as a supporting pedagogical means has brought new and innovating opportunities for students to encounter an endless number of authentic and motivating materials, to engage with subject content, to interact in real-time and exchange meanings with people from other cultures, and to become autonomous, intercultural and collaborative learners (Warschauer, Shetzer, \& Meloni, 2000). These positive effects have been highly appreciated by language teachers seeking to approach pupils in a more innovative and meaningful learning environment beyond the traditional four-wall classroom, where free-access online resources such as language websites have become an increasingly appealing option to achieve this goal.

However, it should also be noted that when resorting to websites for enhancing language learning outcomes, teachers must be aware of its limitations in regards to its internal architecture and its implications on a certain language teaching approach. Thus, in the first place, its possibilities of engaging users in real communicative exchanges appear to be slightly minor, unlike e-learning spaces (e.g., Blackboard, WebCT) that are capable of simultaneously providing a multiplicity of management, communication and interaction features. Therefore, websites may exhibit some difficulties in terms of: (a) integrating asynchronous and synchronous communication tools that facilitate spontaneous language production; (b) centering more on discourse, contexts and culture rather than solely focusing on forms; and (c) giving less limited feedback that surpasses the automatic treatment of errors (Cruz, 2003; E. Fernández, 2007; García, 2000; Kartal, 2005; Lozano \& Ruiz Campillo, 2009; Magnúsdóttir, 2010; Torat, 2000).

Consequently, the majority of websites tend to present language grounded on a behaviorist approach, by promoting deductive grammar explanations as well as structuralist and audio-lingual exercises (e.g., multiple-choice and close-ended questions, true or false items, and fill in the blank, drills) that do not account for the authentic use of the target language. This has been mainly facilitated by the ease, attractiveness and immediate feedback delivery that authoring programs such as Hot-Potatoes and WebPractest commonly offered to create language content (Cruz, 2002; Kartal, 2005; Magnúsdóttir, 2010), which in turn has led to a significant increase and neverending supply of free-access websites that do not necessarily guarantee its overall quality and pedagogical potential.

Hence, and unlike what everyone might think, web-based teaching undeniably constitutes a difficult and demanding task for educators, as they might probably do not know to what extent websites support an effective communicative language learning process and which sites to choose from the wide array of possibilities offered by the Internet (Hassan \& Fakulti, 2011; Son, 2005; Susser, 2001; Yang \& Chan, 2008). This is the reason why teachers need to be discerning and thoughtful when deciding on the most reliable, practical and valid online resources, which should be ideally built on the principles of a teaching approach that encourages free and creative expression of the target language in realistic communicative contexts.

In this sense, as 21st century citizens, educators are being asked to acquire the Knowing-how-todo skill as part of their Digital Competence (European Parliament and European Council, 2007) to be able to evaluate the instructional purposes and language teaching objectives of any online resource just before taking it to the class (Hubbard, 2006; Nomdedeu, n.d.). Thus, the need arises for a website evaluation model (Checklist) that initially guides them to efficiently find and judge the overall appropriateness of any language site in terms of its technical and pedagogical (i.e., learning potential driven by the Communicative Approach) properties and capacities, so that they gradually gain expertise in this field while growing in their Knowing-how-to-do skill, as it is the case of the target population that participated in this study.

Therefore, with the purpose of addressing this issue, the present paper follows this general structure: first, it situates the reader in the literature review section that encompasses topics such as 
website, the Communicative Approach, CALL evaluation and Digital Competence, and then it displays the four-phase methodology used to conduct this research along with the findings, discussion and conclusion sections.

\section{Approaches to Language-Learning Website Evaluation}

The increasing implementation of websites to supplement language learning instruction has driven teachers and researchers to undertake the task of evaluating its value, effectiveness and quality. The growing literature in this field has provided multiple checklists models that encompass a global set of features related to the interface and aesthetics of the site, its functionality, usability, efficiency, navigation, reliability, authority, unity and some other technical elements that facilitate users' experience when surfing online and which should be reflected in general types of sites. Additionally, a few of these checklist proposals integrate a pedagogical dimension, but mostly focus on measuring linguistic variables that include controlled practice exercises of receptive language skills, grammar explanations, vocabulary lists, drilling, as well as aspects comprising instruction delivery, learning objectives, target audience and the difficulty level of exercises. Table 1 shows a brief description of some of these models.

It is important to indicate that evaluating a language website is not just a matter of judging its general layout and the elements that solely enhance learners' linguistic competence; it should also attempt to look for those features that promote a more authentic and creative use of the target language. Thus, autonomy, language contextualization, integration of the four language skills, interculturality, interaction and evaluation (Cruz, 2002; Hita, 2004; Higueras, 2010; Luzón \& Soria, 1999; Richards \& Rodgers, 1986) become principles capable of promoting within website communicative language-learning processes directly dependent on the level of capacities and functionalities these kinds of online resources possess. Moreover, these evaluation models focus specifically on the sites' intrinsic properties but are not concerned with, for example, what learners will be able to do, in terms of language learning cognitive processes, when surfing its contents.

Table 1: Existing evaluation criteria for websites and online materials

\begin{tabular}{|c|c|}
\hline Author(s) & Evaluation Criteria \\
\hline $\begin{array}{c}\text { Stoker \& } \\
\text { Cooke (1994) }\end{array}$ & $\begin{array}{l}\text { 1. Authority } \\
\text { 2. Genealogy or origin of the source } \\
\text { 3. Scope and treatment (purpose, coverage, currency and methods of revision, ac- } \\
\text { 4. Furacy, objectivity, audience) } \\
\text { 5. Arrangement } \\
\text { 6. Technical considerations } \\
\text { 7. Price and availability } \\
\text { 8. User support }\end{array}$ \\
\hline $\begin{array}{l}\text { Marquès } \\
\text { (1999) }\end{array}$ & $\begin{array}{l}\text { 1. Functionality and usability } \\
\text { 2. Technical and aesthetic features } \\
\text { 3. Pedagogical and psychological features (motivation capacity to be attractive and } \\
\text { interesting, adaptation to users' characteristics and needs, didactic resources po- } \\
\text { tentiality, self-learning and initiative encouragement) }\end{array}$ \\
\hline $\begin{array}{c}\text { Lázaro \& } \\
\text { Fernández } \\
\quad(2000)\end{array}$ & $\begin{array}{l}\text { 1. Identification of the material (recipients of the information, level of activities, } \\
\text { 2. Authorship } \\
\text { 3. Navigation } \\
\text { 4. Interface } \\
\text { 5. Functionality and usability }\end{array}$ \\
\hline
\end{tabular}




\begin{tabular}{|c|c|}
\hline Author(s) & Evaluation Criteria \\
\hline Son (2005) & $\begin{array}{l}\text { 1. Purpose } \\
\text { 2. Accuracy } \\
\text { 3. Currency } \\
\text { 4. Authority } \\
\text { 5. Loading speed } \\
\text { 6. Usefulness (convenient information and language activities) } \\
\text { 7. Organization } \\
\text { 8. Navigation } \\
\text { 9. Reliability } \\
\text { 10. Authenticity (language learning authentic materials) } \\
\text { 11. Interactivity } \\
\text { 12. Feedback } \\
\text { 13. Multimedia } \\
\text { 14. Communication (Bidirectional communication among learners) } \\
\text { 15. Integration of the online material into the curriculum }\end{array}$ \\
\hline $\begin{array}{c}\text { Aly } \\
(2008)\end{array}$ & $\begin{array}{l}\text { 1. Authority } \\
\text { 2. Purpose } \\
\text { 3. Coverage } \\
\text { 4. Currency } \\
\text { 5. Objectivity } \\
\text { 6. Accuracy } \\
\text { 7. Technical aspects } \\
\text { 8. Usefulness for EFL Teachers and Students (usefulness and helpfulness in devel- } \\
\text { oping learners' four language skills, grammar, vocabulary and pronunciation) }\end{array}$ \\
\hline $\begin{array}{l}\text { Higueras } \\
(2010)\end{array}$ & $\begin{array}{l}\text { 1. Technical aspects } \\
\text { 2. Reaping the benefits given by the online environment } \\
\text { 3. Profitability of internet access } \\
\text { 4. Reliability } \\
\text { 5. Amount of information provided for the teacher and student }\end{array}$ \\
\hline $\begin{array}{c}\text { Kartal \& } \\
\text { Uzun (2010) }\end{array}$ & $\begin{array}{l}\text { 1. Physical characteristics } \\
\text { 2. Contextual characteristics (features of the site content such as testing tools, } \\
\text { software, lesson plans, exercises) } \\
\text { 3. Pedagogical characteristics (features that contribute to the learning and } \\
\text { teaching process) }\end{array}$ \\
\hline $\begin{array}{l}\text { Liu, G., Liu, } \\
\text { Z., \& Hwang, } \\
\quad \text { (2011) }\end{array}$ & $\begin{array}{l}\text { 1. Web usability } \\
\text { 2. Learning materials } \\
\text { 3. Functionality of assisting language learning (offers multi-channel and hyperme } \\
\text { promoting language learning), } \\
\text { 4. Technology integration (inclusion of technological resources to enhance the websi } \\
\text { its users) }\end{array}$ \\
\hline
\end{tabular}

Therefore, the present study contributes to the literature of language website evaluation by providing a multidimensional checklist based upon the theoretical framework of the Communicative Approach, which, additionally, seeks to augment the teachers' sense of self-confidence and critical thinking when selecting the language sites that best match their language teaching purposes.

\section{Theoretical Framework}

This research study was guided by a review of relevant scholarly literature on the topics of Website, Communicative Approach in virtual environments, CALL evaluation and Digital Compe- 
tence. The contributions given by the authors provided background information to support the construction of the Checklist model and the Study Guide derived from this project.

\section{Website}

The large supply of available free-access online resources has become, in recent years, an increasing trend in language education. Specifically, Websites, as innovative digital settings and as part of new technology, have been highly recommended and used to supplement and enhance language learning. Authors such as E. Fernández (2007) have defined these resources as a collection of webpages interrelated to each other by hyperlinks hosted in a same URL (Uniform Resource Locator) that are created for specific purposes (García, 2000; Higueras, 2010; Marquès, 1999; Nomdedeu, n.d.); in this case, for promoting language learning practices by including several activities, exercises, links and extra tools (Mangenot, 1998). In relation to this, it is important to clarify that Websites or Sites are not the equivalent of Webpages (Codina, 2000; Higueras, 2010) since, unlike what people might commonly think, these latter consist of a single page information or document contained within a website, characterized for being written in a HTML (HyperText Markup Language) format (E. Fernández, 2007) that enables hypertextuality and hypermedia (Rodríguez, 2004) to take place.

Thus, the technological potential of Websites and what make them suitable supporting instructional materials come from its internal architecture design that encompasses useful features such as Hypertext, Multimedia, Hypermedia and Interactivity (Area, 2009). First of all, Hypertext refers to a non-linear system of interconnected documents that allow users to decide on the pathways to follow through the site. Multimedia integrates several forms of information content such as text, audio, graphics and animations. On the other hand, Hypermedia is related to the combination of hypertext and multimedia used for instruction, entertainment and information management. And finally, Interactivity comprises the possibility for users to receive any kind of automatic feedback as a response of a given action.

Apart from these elements, if the aim is to maximize the user's experience when surfing a quality site, it should also provide: (a) an easy accessible and intuitive interface design that encompasses attractive and motivating colors, illustrative, explanatory or decorative images, icons as well as frames that enable the site to be divided into independent areas; (b) an efficient and understandable navigation system design (i.e., dropdown menus, toolbars, sidebars, etc.); and (c) a tree design structure that hierarchically indicates the site's content in order to simplify the browsing paths (Calero, cited by García, 2000). These attributes directly affect users' disposition towards learning a target language as they make websites more user-friendly, appealing and reliable environments, just as has been considered by authors such as Aly (2008), Higueras (2010), Kartal and Uzun (2010), Lázaro and Fernández (2000), Marquès (1999), and Stoker and Cooke (1994), who were presented in the previous section.

Finally, it is worth noting that websites can be classified in relation to its general structure, hyperlink patterns and the editors' purposes (Area, 2009; Gonzalo, 2006; E. Fernández, 2007; Marquès, 1999; Nomdedeu, n.d.). In this sense, when browsing the net, users might encounter: search engines created to crawl, index and search for online information; web directories of categorized webpages interconnected by hyperlinks; corporate sites of commercial nature with a limited number of links to other sites; hosting services where several websites are housed (Gonzalo, 2006); personal sites designed to display the editor's curriculum; and finally, sites for education, specifically created to facilitate learning and provide didactic resources (Marquès, 1999). This latter, within the language teaching context, consists primary of a series of linguistic exercises that take advantage of hypertextuality, multimedia and interactivity elements to promote language practice (Cruz, 2004), also known as "self-access CALL materials" (Mishan, 2013) intended for independent study and as a complement to classwork (Chuo \& Kung, 2002). 


\section{The Communicative Approach in Virtual Environments}

In the present research study, the Communicative Approach will be considered as the theory of language learning that advocates for the development of the communicative competence by which students are able to use the target language appropriately and effectively in real communication contexts. To accomplish this goal, authors such as Canale and Swain (1980), Chamorro (2009), Higueras (2010), Hita (2004), Luzón and Soria (1999), Melero (2004), Richards and Rodgers (1986), have pointed out that language education should meet fundamental communicative principles such as: (a) place students at the center of the process to allow them greater autonomy; (b) encourage exchange and negotiation of meanings; (c) foster interaction and the integration of the four language skills; (d) make emphasis on learning and its formative assessment; and (e) always contextualize the language.

In this regard, and with the growing interest in technology potentials, online resources have been considered instructional materials par excellence to meet the above principles (Adell, 1995; Cruz 2002; Higueras, 2010). Thus, for example, language websites are capable of promoting to a greater or lesser extent the communicative and meaningful use of the target language by integrating the following properties.

On the first hand, there is the Hypertextuality that allows language learners to manage the site's content and choose the order of discourse; an action that activates their rational thinking by favoring the interconnection between prior and present knowledge and, consequently, arousing their capacity for reflection, analysis and interpretation (Cruz, 2002). One of its greatest advantages is that it gives students the choice to take different pathways in relation to their interests, communicative needs, learning styles and pace as well as their language level, a feature that promotes an active and more autonomous role rather than a passive stance (Higueras, 2010; Mao \& Kung, 2001).

Besides, hypertext websites enables users to gradually approach and explore new cultures where the linguistic component is embedded into the cultural one and vice versa (García, 2000), so that by practicing the target language they are able to conduct intercultural exchanges and understanding (Luzón \& Soria, 1999).

Then, there is the Multimedia that favors knowledge contextualization (Cruz, 2002; Higueras, 2010; Luzón \& Soria, 1999), enables practice on receptive language skills (Caridad, 2008), potentiates understanding by simultaneously activating perception senses, and boosts motivation to learning (Mao \& Kung, 2001). Moreover, it not only encourages unidirectional communication (i.e., user-machine) but also interaction among users and provides a vast amount of authentic (Cruz, 2002) or pseudo-authentic materials that enhance the website's attractiveness and the students' engagement.

For its part, the Hypermedia promotes learning-by-doing in which students are given the possibility to interact with different multimodal presentations (e.g., text, audio, animation, videos, etc.) as it immerses them in a living and dynamic context where language is embedded in culture, so that they can learn within an enriched environment of diverse communicative situations (Cruz, 2002; Liu, 1994). Additionally, it involves learners in an active role whereby through linking and manipulating images, text and videos they become creative users and strengthen their language skills while being motivated to solve specific tasks.

There is also the Interactivity, commonly understood in terms of unidirectionality, by which the communicative exchange between user and machine places the student in the role of a transmitter and receiver (Haack, cited by Caridad, 2008; Màrques, cited by Higueras, 2010; Mantilla, n.d.), constituting a basic level of interaction. However, owing to the internal design limitations of most websites, bidirectionality (i.e., user-user), and thus authentic communication, cannot be easily 
achieved, being the reason why it is advisable that sites link users to external resources or at least, propose a series of activities to be conducted in a face-to-face classroom setting.

In addition to the above, interactivity has been as well defined in relation to the feedback provided by websites as a response to learners' input after solving any language exercise or activity. Commonly, language sites offer an automatic close-ended feedback that confirms whether an answer is right or wrong by matching it with predetermined patterns (Caridad, 2008) or giving short explanations. This is what make sites good at strengthening receptive skills through the integration of controlled practice exercises but unable to provide a more flexible feedback system that comprises productive language skills as, unlike e-Learning environments, they would require having an online tutor to guide the learning process (S. Fernández, 1988). Furthermore, despite the feedback immediacy and its possibility of stimulating students' self-correction (Lobin \& Rösler, 2012), the errors treatment is still very limited and does not account for learners' ability to communicate in the target language.

Finally, there are the $C M C$ (Computer-Mediated Communication) tools that represent essential resources to foster effective exchange of meanings and language practice, as they encompass synchronous and asynchronous communication. Thus, the former enables real-time interpersonal communicative exchanges and collaboration among users, encouraged by the implementation of chats, audio-conferencing, instant messaging, among other services that contribute to enhancing learning motivation, the integration of the four language skills and the promotion of collaborative learning and group work (Cruz, 2002; García, 2000). On the other hand, the latter allows the transmission and interchange of information over a period of time via e-mail, listservs, discussion boards, and so forth. These tools encourage students to focus on revising the formal aspects of their messages (i.e., grammatical correctness), the discourse order, the needed vocabulary and the sociolinguistic competence (Rodríguez, 2004), with the aim of gaining self-awareness on the accuracy of the language.

It is worth noting that both these types of online communication tools, especially the synchronous one, are particularly favored in an e-Learning environment (Luzón \& Soria, 1999) due to its intrinsic architecture supported by learning management systems and a wide range of applications, which, unlike language websites, do promote to a higher extent personal telematic communications and thus authentic contexts to perform communicative activities.

\section{CALL Evaluation}

With the advent of the Internet and its implications in the language teaching and learning context, educators are compelled to possess knowledge and expertise in the CALL field. It involves acquiring practical skills to implement several online materials (e.g., websites) as well as the ability to take a critical and reflective stance for evaluating them in the light of their privileged language teaching approach. This is why, during the past years, researchers and teachers have provided several evaluation proposals in the form of methodological frameworks (Chapelle, 2001; Hubbard, 1996; Plass, 1998), surveys (Hubbard, 2003; Knowles, 1992; Robb \& Susser 2000), checklists (Chapelle, 2001; Cruz, 2002; Higueras, 2010; Hubbard, 2006; Lázaro \& Fernández, 2000; Marquès, 1999; Son, 2005; etc.) and some other assessing methods to alleviate the language teachers' complex and time-consuming labor of judging the learning potential of any virtual environment.

In this sense, CALL evaluation has focused on conducting a systematic process to establish the quality, efficiency, overall value and suitability of a given technological material (e.g., software, online course, website, etc.) in order to make a decision on its possible integration into a particular language learning setting (Chapelle, 2001; Hubbard, 2006; Levy \& Stockwell, 2006; Robb \& 
Susser, 2000). This in turn has also implied building evaluation models following three specific aspects that should go hand-in-hand: an approach, a purpose and a method (Duignan, 2003).

To embark on this task, the first step is to think of an approach, which refers to a "way of looking at or contextualizing evaluation" (Duignan, 2003, para.1). This can be done by centering on implicit or explicit theoretical assumptions or a set of values that judge the level of congruency between the material's intrinsic properties and its capacity to support learning from a specific language notion (e.g., Communicative Approach) (Hubbbard, 2006).

Then, it is important to determine the purpose, which aims at "identifying what evaluation activity is going to be used for" (Duignan, 2003, para.1). It entails deciding on two different modalities of CALL evaluation: the formative and the summative one. The former takes place during the development of a new material and seeks to identify its strengths and possible drawbacks in order to improve it before being approved for use, whilst the latter is done after the completion of the material and aims at determining whether it works well or not for the intended purpose; that is, to boost language learning (Chapelle, 2001, Colpaert, 2004; Levy \& Stockwell, 2006; Ma, 2008).

In addition to the above, it is worth noting that the summative evaluation type comprises three levels of analysis: two judgmental-based and one empirical (Chapelle, 2001). On the first level, the CALL material, is decontextualized as the teacher has not used it within a language class and he/she is in the initial process of choosing the most appropriate one from a wide range of possibilities (also conceived by Squires \& McDougall (1996) as predictive or selection evaluation and by Reeder et al. (2004) as introspective). Meanwhile, the second level implies the way in which the teacher plans the material's application for a specific context. And the third one reflects on the user's learning outcomes from the material.

Finally, there is the need to think of an evaluation method or instrument (e.g., consultations, participant observations, interviews, key informant surveys and questionnaires, checklists, etc.) that leads to the collection, disclosure and subsequent analysis of data from the evaluated object (e.g,. learning material) (Duignan, 2003, para.1). Thus, for example, within the CALL evaluation field, the checklist has been considered as one of the most common and practical instruments highly used by language teachers and researchers to gain "insights on how well a particular program, Web site, or online course is working" (Levy \& Stockwell, 2006, p. 45), especially when conducting a first level judgmental evaluation (Chapelle, 2001; Reeder et al., 2004).

This assessment tool is frequently built on a set of evaluation criteria and descriptors presented in the form of questions, categories, features, statements or explanations that aim at issuing a quantitative or qualitative measure over a specific level of accomplishments met by the evaluated object (Levy \& Stockwell, 2006; Rodríguez, 2012; Vela, n.d.). In this sense, evaluation descriptors under each criterion are advised to be formulated based on three different elements: action, content and condition (Campoverde, 2006), which, despite being used for judging students' performances, may also account for the CALL materials intrinsic properties to foster quality language learning processes (Díaz \& Moncada, 2014).

Therefore, the action part of descriptors denotes an achievement expressed in an active verb (i.e., third-person singular) that responds to the question "what language learners will be able to do as a consequence of the CALL material's features?" Verbs can be written following the revised Bloom's taxonomy by Anderson and Krathwohl (2001), who shifted the thinking skills from nouns to verbs, repositioned them and listed them in the form of cognitive processes (Low Order Thinking Skills - LOTS - to Higher Order Thinking Skills - HOTS). Thus, for example, the verb "remembering" implies an information retrieval cognitive activity that can be easily promoted by language-learning materials such as websites. 
Additionally, the evaluation descriptor is composed by the content to which the action is related to, as well as the condition under which this action is expected to be performed (i.e., resources, facilities, tools, etc.). Table 2 exemplifies how these elements join together to become possible evaluation descriptors within a checklist.

Table 2: Examples of evaluation descriptors (HOTS/LOTS)

\begin{tabular}{|c|c|c|c|}
\hline \multirow{2}{*}{$\begin{array}{l}\text { Cognitive } \\
\text { process }\end{array}$} & \multicolumn{3}{|c|}{ CALL material (e.g., website) allows learners to: } \\
\hline & Action & Content & Condition \\
\hline Creating & Generate & $\begin{array}{c}\text { attitudes of openness and em- } \\
\text { pathy towards the target cul- } \\
\text { ture }\end{array}$ & $\begin{array}{c}\text { by including texts, readings and/or vid- } \\
\text { eos that address issues such as immigra- } \\
\text { tion, political debates, human rights, } \\
\text { among others }\end{array}$ \\
\hline Evaluating & Check & their oral comprehension & $\begin{array}{l}\text { by clicking on the transcription button } \\
\text { for video or audio }\end{array}$ \\
\hline Analyzing & Compare & $\begin{array}{c}\text { cultural traits of various speak- } \\
\text { ing regions of the target lan- } \\
\text { guage }\end{array}$ & $\begin{array}{l}\text { by integrating topics of cultural interest } \\
\text { that have influenced people's lives (e.g., } \\
\text { popular culture, politics, history, etc.) }\end{array}$ \\
\hline Applying & Carry out & $\begin{array}{c}\text { oral and written activities that } \\
\text { imply a communicative pur- } \\
\text { pose }\end{array}$ & $\begin{array}{l}\text { by offering rich input (e.g., journals, } \\
\text { videos, recordings, etc.) and encourag- } \\
\text { ing input elaboration }\end{array}$ \\
\hline Understanding & $\begin{array}{c}\text { Inductively } \\
\text { Infer }\end{array}$ & $\begin{array}{l}\text { the uses of certain grammatical } \\
\text { forms }\end{array}$ & $\begin{array}{l}\text { by providing input enhancement (e.g., } \\
\text { capital letter, boldface, underlining, ital- } \\
\text { ics, etc.) }\end{array}$ \\
\hline Remembering & Identify & $\begin{array}{l}\text { in a particular exercise or ac- } \\
\text { tivity their right answers and } \\
\text { correct the errors }\end{array}$ & by clicking on the auto-feedback button. \\
\hline
\end{tabular}

It is worth noting that when exploring any learning material, language learners can be stimulated to activate cognitive skills of different levels depending on the provided input and the intrinsic capabilities of the material.

\section{Digital Competence}

In this emerging knowledge society, Digital Competence has been regarded as one of the eight lifelong learning competences every person must possess in order to effectively use and take advantages of the digital tools at hand (European Parliament and European Council, 2007). It has been even considered as a transversal area that enables people to acquire the other seven fundamental competences, which are communication in the mother tongue, communication in foreign languages, mathematical and basic competence in science and technology, learning-to-learn, social and civic competence, sense of initiative and entrepreneurship, and cultural awareness and expression (Ferrari, 2013).

Within the educational field, particularly in the language-teaching context, Digital Competence has been gaining a lot of attention due to the increasing learning opportunities associated with the rapid development of new technologies and its innovative uses. Consequently, language teachers, as " $21^{\text {st }}$ century citizens of the world," have been expected to be more than competent to know why and how to implement technology into their classrooms, to evaluate its appropriateness and suitability for their intended teaching objectives as well as to conscientize students about its educational potential (Fotos \& Brown, 2004; Instituto Cervantes, 2012). This has implied mastering and applying basic technology-related ICT instrumental and cognitive abilities resulting from the educators' own Knowledge, Attitudes and Skills, three constituent learning domains of any competence (Lara, 2012). 
Thus, the first domain involves the understanding of the digital and technical language, the means by which it is materialized as well as its role and the opportunities it provides for users (Knowing). The second one entails an active participation and responsible citizenship to be functional in a digital environment, where values, aspirations and priorities are key elements to act and interact appropriately (Knowing how to be). And the last one refers to a practical knowledge by which individuals posit a critical and reflective mindset when searching, analyzing and selecting suitable digital tools or materials (e.g., websites) and their ability to use them to perform specific tasks (Knowing-how-to-do skill).

This latter domain suggests that language teachers become third reviewers or "third-party evaluators" (Levy \& Stockwell, 2006, p. 46), responsible for judging the overall quality and appropriateness of a given online learning material based on their specific teaching approach, the learning context, the curriculum and their students' needs. Nonetheless, this is not an ability that can be gained overnight; it requires having background knowledge and expertise in CALL evaluation (Tecnologías Educativas, cited by Lion, 2012), what initially implies making use of helpful assessing methods (e.g., checklists) before being critically prepared to evaluate instinctively.

\section{Methodology}

\section{Participants}

Population of this research study encompassed a convenience small group of language teachers who were taking the MA in Applied Linguistics to the Spanish as a Foreign Language at a Private University (Bogotá, Colombia). Six participants were voluntarily chosen to whom a needs analysis data-collection instrument was administered in order to determine their expertise when selecting CALL materials coherent with their class' language teaching approach. Additionally, a semistructured interview was applied to a language college professor, which sought to explore and deepen on her experiences and practices on this same issue. Finally, a single participant of the target population was selected to review and pilot test the resulting products of this project.

\section{Research Design}

The methodological approach was guided by a mixed qualitative and quantitative research paradigm (Hernández, Fernández, \& Baptista, 2006; Tashakkori \& Teddlie, 2003) that made use of a four-phase sequential procedure to have a better comprehension of the research problem and, thereafter, to develop and validate the resulting products of this project (i.e., the websites' evaluation checklist and the study guide).

This implied starting with a qualitative stage that aimed at exploring, identifying and understanding the initial variables of the study in order to gain insights into the problem and propose a possible solution (Hernández et al., 2006). Thus, in the first place, a semi-structured interview was done and audio-recorded, then it was transcribed so that researchers could read through the raw data, recognize recurring themes and find relations among them, to finally interpret them and set core categories or variables. Later on, an open-ended questionnaire was conducted and analyzed following the same procedure applied to the interview. The last step was executing a data triangulation process (Patton, 1990; Tashakkori \& Teddlie, 2003) by which findings collected from these both methods were compared and verified, and subsequently confronted with relevant literature in order to corroborate its validity and seek for possible convergences and divergences among them. This resulted in a series of problematic issues that allowed researchers to have a general comprehension of the nature of the research problem and thus to set an appropriate research question as well as the objectives that would lead this study. 
Afterwards, this project followed three quantitative stages that mainly focused on measuring and controlling the variables (Fernández \& Baptista, 2006) resulting from judging the quality and suitability of the proposed Checklist model and the Study guide so as to improve them.

Therefore, during the first stage, a survey adapted from Yang \& Chan (2008) was applied to the Checklist model by one expert in the CALL field which, through a content and construct validity assessment (Kelley, 1999; Rubio, Berg-Weger, \& Tebbs, 2003), researchers sought to revise whether the evaluation criteria and descriptors corresponded to each other and if these latter were appropriate, representative, important and clear for the criteria they stood for (i.e., technical, pedagogical-contextual and communicative approach-related characteristics) (see Appendix A). Then, after having refined the checklist proposal based on the expert's judgments, in the second stage, the instrument was pilot tested by one of the participants who applied it to a language website; this same was conducted by researchers in order to verify its inter-rater reliability (Seliger \& Shohamy, 1989). Finally, in the third stage, the same participant evaluated both products by means of a survey that inquired about the quality of the study guide as an instructional material and for the checklist structural properties (see Appendix B).

\section{Findings}

Major outcomes from the four-phase procedure conducted in the present research are reported.

\section{Phase I (qualitative stage)}

The first stage was an application to the target population of an open-ended questionnaire and a semi-structured interview to a language college professor, both in the form of a needs analysis that focused on identifying and gaining an in-depth understanding of the research problem. Thus, the gathered information from these collecting instruments served to establish four core categories that became the following orienting problematic issues: (a) the steadily increasing number of websites grounded on a behaviorist language-learning theory; (b) its interface design that, unlike paper-based language materials, should integrate features such as hypertextuality, multimedia, hypermedia and some others, so as to promote communicative achievements; (c) the mismatch found between the teachers' choice of apparently communicative-based language websites and the ones that truly work for this purpose; and finally, (d) the lack of an evaluation instrument that allows language teachers to obtain a true understanding of what a communicative language website should look like. Table 3 displays a sample of the triangulation matrix used to correlate data resulted from both collecting instruments and its confrontation with literature.

The emerging research issues presented led researchers to draw the conclusion that there was a pressing need to propose an evaluation instrument for websites that comprises the principles of the Communicative approach, and that additionally focuses on what students will be able to do within this virtual environment as active participants of their own learning process. This would be with the aim of guiding language educators to make a reliable and informed decision on the most appropriate online material to integrate into class and as a brief training for them to progressively develop their Knowing-how-to-do skill. Thus, right after conducting the need analysis and interpreting the gathered results, researchers started to review literature with the purpose of targeting the first immediate need, which was the development of an initial checklist model. They analyzed and synthesized various checklists evaluation proposals (Table 1) that accounted for what have been done and said about assessing language-learning websites and its intrinsic properties (e.g., structure, organization, functionality, multimedia, content, language learning focus and son on). Based on this review process, it was found that most of the striking features included within these proposals were directly linked to technical aspects, followed by some pedagogical considerations and by a few language approach statements still limited to the linguistic competence, as it can be seen in Table 4. 
Table 3: Triangulation matrix sample

\begin{tabular}{|c|c|c|c|}
\hline \multirow[b]{2}{*}{ Category } & \multicolumn{2}{|c|}{ Direct responses } & \multirow[b]{2}{*}{$\begin{array}{l}\text { General overview of the } \\
\text { revised literature }\end{array}$} \\
\hline & $\begin{array}{l}\text { Participants of the } \\
\text { target population } \\
\text { (survey responses) }\end{array}$ & $\begin{array}{c}\text { Language college } \\
\text { professor } \\
\text { (interview responses) }\end{array}$ & \\
\hline $\begin{array}{l}\text { Behavior- } \\
\text { ist-based } \\
\text { Websites }\end{array}$ & $\begin{array}{l}\text { Teacher 5: "considerar la retroali- } \\
\text { mentación inmediata como fuente de } \\
\text { conocimiento" (to consider imme- } \\
\text { diate feedback as a source of kno- } \\
\text { wledge). } \\
\text { Teacher 1: "ejercicios de completar } \\
\text { los espacios en blanco" (fill in the } \\
\text { gaps exercises). } \\
\text { Teacher 6: "generalmente se encuen- } \\
\text { tran ejercicios de rellenar huecos, ya } \\
\text { sea con información dada de manera } \\
\text { escrita o de archivos de audio" } \\
\text { (generally, it can be found fill in the } \\
\text { gap exercises to be solved with } \\
\text { written or audio file input). } \\
\text { Teacher } 4: \text { "en Internet se pueden } \\
\text { encontrar una variedad de ejercicios } \\
\text { para las habilidades receptivas y la } \\
\text { mayoría son ejercicios gramaticales } \\
\text { mecánicos. Casi no encuentro ejer- } \\
\text { cicios para la producción oral" (On } \\
\text { the Internet you can find a variety of } \\
\text { exercises for the receptive skills and } \\
\text { most of these are mechanical } \\
\text { grammar exercises. I hardly find } \\
\text { exercises for oral production). } \\
\text { Teacher } 1: \text { "hay mucha información } \\
\text { en la Red, sin embargo, está se } \\
\text { encuentra desorganizada" (there is a } \\
\text { lot of information on the Web, } \\
\text { however it is disorganized). }\end{array}$ & $\begin{array}{l}\text { "se llamaban ejercicios } \\
\text { interactivos pero ya con el } \\
\text { tiempo me di cuenta de que } \\
\text { no eran tan interactivos } \\
\text { como pensaba, se brindaba } \\
\text { la respuesta correcta y ya" } \\
\text { (these were called interac- } \\
\text { tive exercises but I eventu- } \\
\text { ally realized that they were } \\
\text { not as interactive as I } \\
\text { thought, they only provided } \\
\text { the correct answer). } \\
\text { "lo que habia eran paginas } \\
\text { enfocadas a las formas } \\
\text { lingüisticas...no hay un reto } \\
\text { más allá y el estudiante no } \\
\text { ve la lengua como instru- } \\
\text { mento para comunicarse" } \\
\text { (there were websites fo- } \\
\text { cused mainly on linguistic } \\
\text { forms...these did not imply } \\
\text { any challenge and the stu- } \\
\text { dent could not regard the } \\
\text { language as a tool for com- } \\
\text { munication). } \\
\text { "el profesor de lenguas...se } \\
\text { siente como bombardeado } \\
\text { por tanta información que } \\
\text { hay en la red" (the language } \\
\text { teacher...feels over- } \\
\text { whelmed by so much in- } \\
\text { formation on the Web). }\end{array}$ & $\begin{array}{l}\text { García (2000) claims that a wide } \\
\text { number of websites focus on } \\
\text { providing grammatical explana- } \\
\text { tions through structuralist exer- } \\
\text { cises, which ultimately relegates } \\
\text { the language communicative } \\
\text { component. } \\
\text { Likewise, Kartal (cited by Kartal } \\
\text { \& Uzun, 2010) outlines that a } \\
\text { great number of language learn- } \\
\text { ing websites have narrowed their } \\
\text { pedagogical approach to struc- } \\
\text { tural exercises with immediate } \\
\text { feedback response. Moreover, } \\
\text { Martín (cited in Cruz, 2003) } \\
\text { indicates that most of the lan- } \\
\text { guage exercises with an interac- } \\
\text { tive look still being traditional, } \\
\text { structuralist-based. } \\
\text { Thus, the majority of those kinds } \\
\text { of online materials offer exercis- } \\
\text { es that enhance a deductive } \\
\text { language learning approach, } \\
\text { favored by the ease of program- } \\
\text { ming of authoring programs such } \\
\text { as Hot-potatoes and Web- } \\
\text { practest (E. Fernández, 2007). } \\
\text { Additionally, the growing offer } \\
\text { of free-access website on the Net } \\
\text { does not directly means quality } \\
\text { (Susser, 2001; Yang \& Chan, } \\
\text { 2008; Son, 2005; Hassan \& } \\
\text { Fakulti, 2011). }\end{array}$ \\
\hline $\begin{array}{l}\text { Interface } \\
\text { design } \\
\text { qualities }\end{array}$ & $\begin{array}{l}\text { Teacher 6: "los criterios que tendria } \\
\text { en cuenta para seleccionar un sitio } \\
\text { web serian la interactividad y la } \\
\text { lecturabilidad" (the criteria I would } \\
\text { take into account when selecting a } \\
\text { website will be interactivity and } \\
\text { readership). } \\
\text { Teacher 1: "que los sitios web no } \\
\text { tengan problemas de plugins" (web- } \\
\text { sites must not have plugin failures). } \\
\text { Teacher 2: "un sitio web debe tener } \\
\text { practicidad" (A website must entail } \\
\text { practicality). } \\
\text { Teacher 5: "No sabe / No responde" } \\
\text { (do not know /do not answer - this } \\
\text { was given as a response to the ques- } \\
\text { tion that inquired for the criteria } \\
\text { participants that take into account } \\
\text { when choosing a language website). }\end{array}$ & $\begin{array}{l}\text { (Nothing was mentioned in } \\
\text { this respect). }\end{array}$ & $\begin{array}{l}\text { Internet-based materials can be } \\
\text { commonly evaluated under the } \\
\text { same criteria used for paper- } \\
\text { based resources, due to the } \\
\text { apparent familiarity between } \\
\text { both of them. In this regards, } \\
\text { Levy \& Stockwell (2000) argue } \\
\text { that, unlike textbooks that imply } \\
\text { a linear reading, websites for its } \\
\text { hypertextual nature need to be } \\
\text { evaluated based on its intrinsic } \\
\text { capabilities, which is why teach- } \\
\text { ers must be third-party evaluators } \\
\text { of this kind of material. } \\
\text { A learning material cannot be } \\
\text { limited to the format; instead, it } \\
\text { must be adapted to the audiovis- } \\
\text { ual culture supported by multi- } \\
\text { media and hypertextuality online } \\
\text { properties (Cruz, 2002). }\end{array}$ \\
\hline
\end{tabular}




\begin{tabular}{|c|c|c|c|}
\hline \multirow[b]{2}{*}{ Category } & \multicolumn{2}{|c|}{ Direct responses } & \multirow[b]{2}{*}{$\begin{array}{l}\text { General overview of the } \\
\text { revised literature }\end{array}$} \\
\hline & $\begin{array}{c}\text { Participants of the } \\
\text { target population } \\
\text { (survey responses) }\end{array}$ & $\begin{array}{c}\text { Language college } \\
\text { professor } \\
\text { (interview responses) } \\
\end{array}$ & \\
\hline $\begin{array}{l}\text { Teacher's } \\
\text { mis- } \\
\text { matching } \\
\text { choice of } \\
\text { websites }\end{array}$ & $\begin{array}{l}\text { Teacher 2: "Me encanta Duolindo, es } \\
\text { interactivo y comunicativo" (I love } \\
\text { Duolingo, it is interactive and } \\
\text { communicative). }\end{array}$ & $\begin{array}{l}\text { "Recuerdo muy bien una } \\
\text { página que a mí me parecía } \\
\text { perfecta...entonces me di } \\
\text { cuenta que realmente los } \\
\text { estudiantes no estaban } \\
\text { haciendo ningún tipo de } \\
\text { negociación ni un intercam- } \\
\text { bio significativo" (I re- } \\
\text { member a website that } \\
\text { seemed to be perfect...then } \\
\text { I realized that students } \\
\text { weren't actually making } \\
\text { any sort of communicative } \\
\text { exchange). }\end{array}$ & $\begin{array}{l}\text { Warschauer (cited by Chapelle \& } \\
\text { Hegelheimer, 2004) argues that } \\
\text { there is a need to rethink the } \\
\text { communication competence in } \\
\text { virtual environments. } \\
\text { It is worth noting that Duolingo } \\
\text { is a crowdsourcing platform that } \\
\text { encourages students to learn the } \\
\text { target language by translating } \\
\text { words and phrases from their } \\
\text { mother tongue and vice versa. }\end{array}$ \\
\hline $\begin{array}{l}\text { Lack of } \\
\text { an as- } \\
\text { sessment } \\
\text { instru- } \\
\text { ment }\end{array}$ & $\begin{array}{l}\text { Teacher 1: "una herramienta de } \\
\text { evaluación permitiría facilitar mi } \\
\text { labor como docente de lengua" (An } \\
\text { assessment tool would make easier } \\
\text { my work as a language teacher). } \\
\text { Teacher } 3 \text { : "sería bueno contar con } \\
\text { una herramienta...que me ayude a } \\
\text { escoger un buen sitio web, dado que } \\
\text { hasta el momento no conozco esos } \\
\text { sitios muy bien" (It would be nice to } \\
\text { have a tool... that helps me to pick } \\
\text { a good website, given that so far I } \\
\text { don't really know those sites that } \\
\text { well). } \\
\text { Teacher } 5 \text { : "nunca me he detenido a } \\
\text { evaluar la concordancia de las } \\
\text { páginas que uso con lo que hago } \\
\text { diariamente en mis clases, entonces } \\
\text { sería bueno tener una herramienta de } \\
\text { evaluación para este propósito" (I } \\
\text { have never considered evaluating the } \\
\text { coherence between the websites I use } \\
\text { daily in my classes, so it would be } \\
\text { great to have an assessment tool for } \\
\text { this purpose). }\end{array}$ & $\begin{array}{l}\text { "yo creo que es bastante } \\
\text { importante que se pudiera } \\
\text { tener un recurso...para que } \\
\text { encuentre una página que } \\
\text { realmente le permita pre- } \\
\text { sentarle a sus estudiantes } \\
\text { un material de apoyo de } \\
\text { calidad... en donde las } \\
\text { instrucciones sean claras, } \\
\text { sencillas y que sobre todo } \\
\text { permita el uso real de la } \\
\text { lengua" (I think it's quite } \\
\text { important to count on with a } \\
\text { resource...to find a websi- } \\
\text { te that truly allows teachers } \\
\text { to provide students with a } \\
\text { quality supporting mate- } \\
\text { rial... where instructions are } \\
\text { clear and overall, leads to } \\
\text { the real use of the langua- } \\
\text { ge). }\end{array}$ & $\begin{array}{l}\text { According to Higueras (2010) } \\
\text { and Magúsdóttir (2010), the } \\
\text { large amount of free-access } \\
\text { websites possess a problem of } \\
\text { discrimination for language } \\
\text { teachers, being this the reason } \\
\text { why, there is a need to count on } \\
\text { with a clear set of criteria that } \\
\text { allow educators to make valuable } \\
\text { judgements on the most appro- } \\
\text { priate websites for the intended } \\
\text { teaching purposes. } \\
\text { Fotos \& Brown (2004) note that } \\
\text { "language teachers are increas- } \\
\text { ingly required to possess CALL } \\
\text { expertise that includes both } \\
\text { practical skills and a thorough } \\
\text { understanding of information } \\
\text { technology theory. Teachers may } \\
\text { need to design, implement and } \\
\text { evaluate CALL activities in their } \\
\text { classroom" (p.3). The same is } \\
\text { considered by authors such as } \\
\text { Son (2005); Levy \& Stockwell } \\
\text { (2006), Chapelle (2001). }\end{array}$ \\
\hline
\end{tabular}

Table 4: Website evaluation proposals

\begin{tabular}{|c|c|c|c|}
\hline Dimension & \multicolumn{2}{|c|}{ Websites features / items } & Authors \\
\hline $\begin{array}{l}\text { Technical } \\
\text { aspects }\end{array}$ & $\begin{array}{l}\text { - Authority } \\
\text { - Authorship } \\
\text { - Accuracy } \\
\text { - Navigation } \\
\text { - Interface }\end{array}$ & $\begin{array}{l}\text { - Usefulness } \\
\text { - Edition settings } \\
\text {-Genealogy or source origin } \\
\text { - Loading speed }\end{array}$ & $\begin{array}{l}\text { Stoker \& Cooke (1994), Marquès, } \\
\text { (1999), Lázaro \& Fernández (2000), } \\
\text { Son (2005), Aly (2008), Yang \& } \\
\text { Chan (2008), Higueras (2010), Kartal } \\
\text { \& Uzun (2010), Dogoritti \& Pagge } \\
(2012)\end{array}$ \\
\hline $\begin{array}{l}\text { Pedagogical } \\
\text { considera- } \\
\text { tions } \\
\end{array}$ & $\begin{array}{l}\text { - Learning materials } \\
\text { - Content } \\
\text { - Difficulty level of activities }\end{array}$ & $\begin{array}{l}\text { - Evaluation information } \\
\text { - Learners' preferences } \\
\text { - Contextual characteristics } \\
\end{array}$ & $\begin{array}{l}\text { Marquès (1999), Trenchs Parera } \\
\text { (2001), Yang \& Chan (2008), Higue- } \\
\text { ras (2010), Kartal \& Uzun (2010) }\end{array}$ \\
\hline $\begin{array}{l}\text { Language } \\
\text { approach } \\
\text { principles }\end{array}$ & - Language skills & $\begin{array}{l}\text { - Feedback delivery } \\
\text { - Communication setting }\end{array}$ & $\begin{array}{l}\text { Son (2005), Yang \& Chan (2008), } \\
\text { Lozano \& Ruiz Campillo (2009), } \\
\text { Higueras (2010) }\end{array}$ \\
\hline
\end{tabular}


Once the literature has been reviewed and researchers have chosen the specific items to include within the Checklist proposal, it was necessary to conduct an additional exploratory search on current Spanish learning websites (e.g., Español para extranjeros http://www.aurora.patricknieto.fr/, RedMolinos http://www.redmolinos.com/, ver-taal http://www.ver-taal.com/, La ruta de la lengua española $h t t p: / / w w w . l a r u t a d e l a l e n g u a . c o m / i n d e x 2 . h t m$, etc.) in order to observe their capabilities and limitations and thus to derive extra features. This whole process resulted in a preliminary Checklist model that encompassed nine evaluation criteria and a total of 40 descriptors included within three evaluation dimensions, as referred as follows:

1. Technical characteristics related to the ease of use (7 descriptors) and reliability criteria (3 descriptors).

2. Pedagogical contextual characteristics referring to the content quality criterion ( 5 descriptors) and the material potentiality criterion, this latter in terms of the provided advantages and benefits ( 2 descriptors).

3. Communicative Approach-related characteristics that reflected on criteria such as autonomy (4 descriptors), language contextualization (5 descriptors), language skills integration (6 descriptors), interculturality (4 descriptors) and interaction (4 descriptors).

Finally, it is important to mention that, during this first stage, a theoretical framework concerning the Communicative Approach principles, the language websites' features and Digital Competence was also taken into account with the purpose of: (a) conducting the triangulation procedure (see Table 3); and (b) establishing the orienting checklist dimensions (i.e., evaluation criteria) along with its descriptors; in particular, the ones implying the Communicative Approach-related characteristics.

\section{Phase II (quantitative stage)}

A four-part validity survey that sought to improve the quality of the preliminary evaluation criteria and descriptors was applied to an expert in the CALL field. This data collection instrument, adapted from Yang \& Chang (2008), asked to carefully revise, rate and provide comments or suggestions for each of the evaluation components that comprised the preliminary proposal. This included judging the appropriateness (i.e., the suitability of a descriptor in relation to the criterion it was proposed for), representativeness (i.e., the descriptor stands for the criterion it was proposed for), importance (i.e., the relevance of the descriptor for the respectively criterion), and clarity (i.e., avoid wording ambiguity) of descriptors, as well as checking their belonging to the proposed criteria (see Appendix A).

The results from this survey (see Figure 1) showed that the evaluation dimension regarding the Technical aspects received an overall assessment of $99.4 \%$, since the descriptors encompassed within the "ease of use" and "reliability" criteria were 100\% representative, important and appropriate, and $97.5 \%$ clear. However, the reviewer recommended that there should be more descriptors concerning the hardware-software technical specifications (ease of use criterion) and one item that inquires for the author(s) of the website (reliability criterion).

On the other hand, the Pedagogical contextual dimension obtained an $85.7 \%$ valuation, as its descriptors were $96.4 \%$ representative, $89.2 \%$ important, $85.7 \%$ clear and $71.4 \%$ appropriate. This revealed that it was necessary to make descriptors more comprehensible and shorter, this by including exemplifications, clarifications, etc. (content quality criterion); likewise, descriptors implying the advantages and benefits of the website could be deleted as they are taken up in subsequent descriptors (material potentiality criterion).

Finally, concerning the Communicative Approach dimension, it could be observed that it got an $82.6 \%$ of accomplishment, as its descriptors showed to be $79.3 \%$ representative, $82.6 \%$ important, $90.2 \%$ clear and $78.2 \%$ appropriate. In this respect, the expert asserted that: (a) the de- 
scriptor about evaluation should be formulated in a way that does not purely imply test taking but a more formative assessment process (autonomy criterion); (b) some of the descriptors tend to make emphasis on linguistic and lexical properties and do not take into consideration other aspects that could promote authentic communication exchanges (language contextualization criterion); (c) three descriptors do not account for the language skills integration (language skills integration criterion); (d) descriptors should include the notion of attitude as one of the important aspects involved in the learning of the target culture (interculturality criterion); and (e) some of the descriptors focused mainly on the machine-student interaction and did not express real exchange of meanings, so for this reason they should be integrated into a new criterion that embraces feedback-delivery (interactivity criterion).

These outcomes were of great help to researchers for gathering useful and important feedback on how well-founded and accurate were the initial evaluation criteria and descriptors. Thus, from this validity survey, 11 evaluation descriptors were revised and improved, and other 19 were incorporated. Even though the findings showed that some of them had wording problems and needed to be rewritten again, they were still appropriate, representative and important.

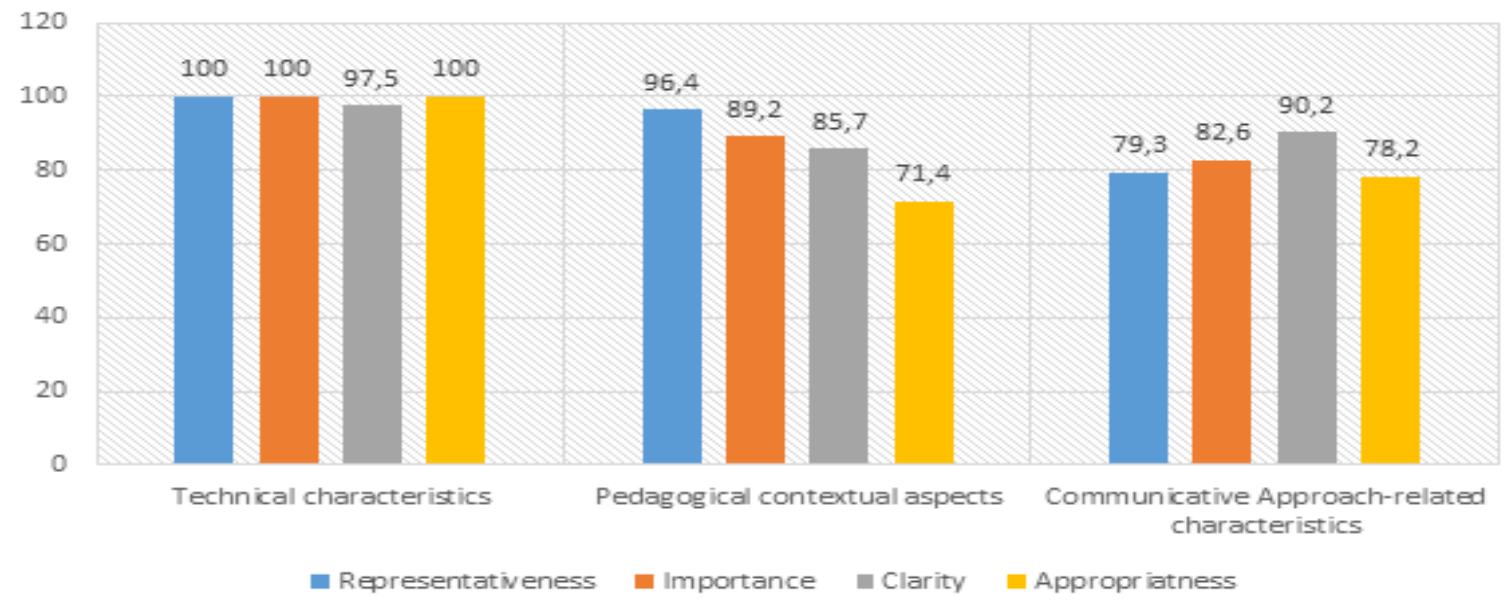

Figure 1: Expert rating over preliminary Checklist proposal

In light of the above, researchers were able to refine the preliminary Checklist model (see Appendix C) and obtain an evaluation tool that comprised a total of 49 descriptors integrated into the three already known dimensions and eight evaluation criteria. This instrument can be used by reviewers or third-party evaluators to judge the value and quality of any language-learning website by simply checking off "Yes" or "No" in the given grid as well as adding some personal comments based on the degree to which the online material meets the intended communicative teaching objectives. Table 5 explains in detail each of the final checklist's components.

Apart from the Checklist model, the other goal of this research project was to strengthen the teachers' Knowing-how-to-do skill as part of their Digital Competence. This was attempted to be accomplished by designing a Study Guide

(https://issuu.com/sthephannymoncadalinares/docs/guiapracticafinal), as a training and informational instructional material that could provide a conceptual and practical framework along with methodological suggestions for educators to become familiar with language-learning websites just before evaluating them. 


\section{Table 5: Checklist evaluation model}

\section{Technical features dimension}

Allow users to recognize at first sight, whether the website is worth exploring and if it serves as a complementary material for the classroom use.

\section{Descriptors:}

- $\quad$ Ease of use criterion (9 descriptors): It covers the website qualities in regards to a friendly, clear, simple, consistent, attractive and motivating graphic interface, aspects that directly affect the user's browsing experience. Therefore, websites for itself should be self-explanatory and not possess any difficulties when browsing it, retrieving information, obtaining learning materials or following hyperlinks.

- Reliability criterion (5 descriptors): It shows that a website is credible when it is possible to identify its developers, it does not present any systematic errors that hinder navigation and hyperlinks do not connect to other dubious sites.

\section{Communicative Approach theoretical dimension}

This criterion aside from being proposed based an approach-driven framework (i.e., Communicative Approach), its descriptors target at describing what students are able to do within the website in terms of Low or High Order thinking skills (Anderson \& Krathwohl, 2001).

30 descriptors:

- Autonomy criterion (4 descriptors): It should promote a self-learning, self-monitored and self-regulating space by the inclusion of hypertextuality and rich contextual hypermedia.

- Language contextualization criterion (7 descriptors): It should introduce language input inductively and additionally, enhance it (e.g., capital letter, boldface, underlining, italics, etc.). Activities and exercise must have an implicit communicative intention and should be supported by various multimedia and hypermedia resources that contextualize knowledge.

- Language skills integration criterion (7 descriptors): In real communication exchange the four language skills are integrated, that is why a language website should ideally encompass authentic materials, multimedia, hypermedia and $\mathrm{CMC}$ tools to achieve this goal. However and differing from an e-Learning platform, researchers are aware that most websites have some intrinsic limitations in this regards, being the reason why they commonly integrate a wide range of receptive skills activities.

- Interculturality criterion (8 descriptors): through the integration of hypertext, multimedia, hypermedia and authentic materials, websites are able to recreate a living and dynamic context where culture is present.

- Evaluation criterion (4 descriptors): the possibility to receive automatic feedback that allows users to selfmonitor and observe their performance when solving different exercises or activities. Some websites apart from the right/wrong remark, place allusive phrases about what students will be able to do or include assessment rubrics.

The main structure of this created material consists of four sections plus a glossary and a reference part:

- Section 1 - What do language teachers need to know? Fundamental concepts related to the notion of Digital Competence, Communicative Approach, websites and its main features (hypertext, multimedia, hypermedia, and feedback tools $\mathrm{CMO}$ ) are presented.

- Section 2 - What are we looking for in language learning websites? The Communicative Approach principles (i.e., autonomy, contextualization of language, integration skills, intercultural interaction and assessment) are displayed in the form of evaluation criteria and descriptors, as they appear in the checklist. This with the aim of illustrating what might possess a certain language website if it is highly communicative. Thus, each descriptor is 
accompanied by a screenshot that represents the available features or resources that meet the teaching and learning expectations, so it can give a visual idea of what evaluators are looking for.

- Section 3 - It is time to evaluate: The assessment instrument (checklist) is presented along with its corresponding instructions.

- Section 4 - Let's talk about design: In order to help direct the work of the reader to a practical exercise, a number of methodological suggestions for the creation and design of a website are provided as an opportunity to put into practice the knowledge acquired throughout the material.

- Glossary: The definitions of eleven terms that may be new to the reader are organized in alphabetical order, giving conceptual clarity of the technicalities referred in the material (e.g., Web search engine, web page, URL, hyperlink, interface, among others).

- References.

This Study Guide was also reviewed by a professional in the language-teaching field, to whom an evaluation survey was administered consisting of 20 questions (see Appendix B). This evaluation was performed in a space of two hours, where the college professor revised the whole instructional material and then completed the survey format. The results showed that most of the material's sections met the objectives for which they were developed, reaching a total score (i.e., over four points $-100 \%$ ) on aspects such as: (a) impact on arousing and sustaining the reader's curiosity and attention by providing attractive presentation, appealing content and activities that boost their active thinking; (b) encouraging readers to feel at ease when facilitating the understanding of contents by including exemplifications, illustrations and other contextualizing resources; (c) developing readers' self-confidence by pushing their skills and knowledge beyond their existing proficiency through activities with a progressive level of difficulty; and (d) promoting selfinstruction. On the other hand, it obtained 3 points (87.5\%) on its capability of offering useful and relevant contents. It is important to mention that these criteria used for evaluating the Study Guide was adapted from Tomlinson's (2011) principles to design effective language-teaching materials.

Furthermore, as the checklist was also part of the Study Guide (section 3), the language professor was asked to judge and evaluate its overall content, from which it received a rating from three to four points in items such as: (a) its structure (three points); (b) the clarity of its instruction delivery (four points); and (c) the quality of its descriptors (four points). The evaluation results from both products can be seen in Table 6 . The outcomes from this second phase of the study allowed researchers to make improvements to the Checklist and the Study Guide before implementing them in a real setting.

Table 6: Language college professor rating on the Study guide and the Checklist model

\begin{tabular}{|c|c|c|}
\hline Evaluation criteria & Given rating & General remarks from the participant \\
\hline \multicolumn{3}{|c|}{ STUDY GUIDE } \\
\hline Materials' impact & $100 \%$ (4 points) & \multirow{5}{*}{$\begin{array}{l}\text { "en la guía se presentan imágenes, glosario, explica- } \\
\text { ciones. Hay llamados o sección "para pensar". Se } \\
\text { observa una secuencia lógica en la presentación de } \\
\text { los contenidos. La presentación de información teóri- } \\
\text { ca le ayuda al docente a desarrollar la autoconfianza" } \\
\text { (the guide displays images, a glossary, explanations. } \\
\text { There is a section called "to think." There is a logic } \\
\text { sequence in the exhibition of contents. The presenta- } \\
\text { tion of theoretical information helps teachers to de- } \\
\text { velop self-confidence). }\end{array}$} \\
\hline $\begin{array}{l}\text { Teacher's development of } \\
\text { self-confidence }\end{array}$ & $100 \%$ (4 points) & \\
\hline Teacher's feeling at ease & $100 \%$ (4 points) & \\
\hline $\begin{array}{l}\text { Perception towards the } \\
\text { displayed contents as rele- } \\
\text { vant and useful }\end{array}$ & $87.5 \%$ ( 3 points $)$ & \\
\hline Teacher's self-instruction & $100 \%$ (4 points) & \\
\hline
\end{tabular}




\begin{tabular}{|c|c|c|}
\hline Evaluation criteria & Given rating & General remarks from the participant \\
\hline \multicolumn{3}{|c|}{ CHECKLIST MODEL } \\
\hline Structure & $\begin{array}{c}91.6 \% \\
(3 \text { points })\end{array}$ & \multirow{3}{*}{$\begin{array}{l}\text { "En general, la lista de chequeo presenta los criterios } \\
\text { de evaluación de forma y concisa. Por su parte, los } \\
\text { descriptores son fáciles de entender y están organiza- } \\
\text { dos de manera secuencial" (In general, the checklist } \\
\text { presents contents in a clear and concise way. For its } \\
\text { part, descriptors are easy to understand and are orga- } \\
\text { nized in a sequential fashion). }\end{array}$} \\
\hline Clarity of instructions & $\begin{array}{c}100 \% \\
(4 \text { points) }\end{array}$ & \\
\hline $\begin{array}{c}\text { Quality of the evaluation } \\
\text { descriptors }\end{array}$ & $\begin{array}{c}100 \% \\
(4 \text { points) }\end{array}$ & \\
\hline
\end{tabular}

\section{Phase III (quantitative stage)}

With the purpose of applying and testing the quality and efficacy of the proposed Checklist mod$\mathrm{el}$, it was necessary to pick one language-learning website. The selection was conducted by typing in the Google search engine entries like "Spanish language-learning websites", "the best language websites to learn Spanish", etc.; then, from the wide array of possibilities and after skimming and scanning some of the retrieved sites that were free access no-cost, reliable and useful as they integrated a variety of contents, activities and resources, the "Español para extranjeros" (http://www.aurora.patrick-nieto.fr/) website was chosen.

During this third stage of the research, one participant of the target population was asked to use the Checklist in order to evaluate the previously selected online environment. First, she received a copy of the Study Guide for her to read thoroughly; then, she was requested to familiarize with the site, surfing and exploring its various options and pathways; and finally, she was encouraged to apply the evaluation instrument to this site.

Findings regarding this assessment process showed that, in general, the website accomplished in $60.7 \%$ the descriptors encompassed within the three evaluation dimensions (i.e., technical, pedagogical-contextual and the Communicative Approach-related characteristics), being ranked as a "Good (appropriate for use)" complementary material for meeting 29 out of 49 evaluation items.

Thus, within the dimension of technical features, the site met in 59\% the evaluation criteria, as it proves to have free and no-cost access, it is easy to use as it displays a friendly and attractive interface that provides navigation guidance to users, makes use of a clear and precise language and, in addition, has an appropriate balance between the textual and multimedia content. However, browsing can be a bit difficult because it lacks permanent frames that allow the use of its independent controllable sections. On the other hand, the site seems to be reliable as it is claimed to be the result of a teaching project developed by its authors, who pointed out that it is founded on the constructivism and notional-functional theoretical framework; nonetheless, information related to its permanent updating is not presented.

Some of the participant's comments that support her rating over this category include: "no veo las pestañas" (I don't see the tabs), "yo le añadiría otros colores un poco más vivos" (I would add more vivid colors), "los enlaces son muy llamativos" (the hyperlinks are too eye-catching), "veo que en algunas ocasiones el azul y el morado se confunde en las instrucciones y en los títulos" (I see that sometimes blue and purple blends into the instructions and the titles), "no lo veo ni es visible para mí la actualización" (the uptading option isn't visible for me), and "se basa en las teorias de Piaget y Vigotsky, tal como se señala" (it is based on Piaget and Vigotsky's theories, just as it is indicated).

In regards to the dimension of pedagogical-contextual characteristics, the website reached a success rate of $60 \%$, since it includes a variety of contents, activities and resources, displays short and understandable instructions and introduces grammar points inductively. Nevertheless, it does not present the learning objectives pursued by the realization of the different activities and exer- 
cises nor indicates its language level of difficulty, as the participant underlines: "no hay objetivos planteados al inicio de cada tarea ni su nivel de lengua" (neither the goals nor the language level are presented at the beginning of each task).

Finally, in relation to the Communicative Approach principles dimension, the website got a $63 \%$ of success, meeting 17 out of 30 evaluation descriptors. It proves to have a stronghold in promoting autonomy, language contextualization and evaluation, as it allows students to freely choose and make decisions on the pathways they are interested in following within or outside the site, it offers different types of resources (e.g., multimedia, authentic materials, etc.) that contextualize knowledge and facilitates the understanding of the target language, and additionally provides both explicit and implicit feedback that favor the recognition of the students' strengths and weaknesses. Nonetheless, it fails to provide tools (e.g., evaluation rubrics) for monitoring their own language learning performance in terms of productive skills.

It is worth noting the website has some disadvantages when trying to successfully foster interculturality and interaction as, for example, it relies on a single sociocultural perspective coming from the peninsular Spanish and does not take into consideration other Spanish speaking regions; likewise, it does not integrate or link users to other sites that encompass CMC tools that could approach them to interact with people and thus promote authentic and meaningful learning situations, as evidenced by the participant who asserted that "en los ejercicios que exploré, yo no encontré herramientas CMO" (within the exercises that I explore, I couldn't find CMC tools). It also has some weaknesses with respect to the integration of language skills, because it does not include authentic sounds, such as songs and everyday dialogues, that could enhance the oral comprehension and, on the contrary, it mainly focuses on receptive skills. However, this site does provide learners with a series of printable complementary activities that offer practical application of the language communicative skills and, despite being paper-based, they can successfully enhance oral communication by means of teamwork activities in class.

Table 7 portrays the results obtained from evaluating this site and compares the participant and the researchers' results, who also evaluated it with the purpose of testing the inter-rater reliability of the Checklist model in relation to the consistency and accuracy between both responses.

Table 7: Results of evaluation of the website Español para extranjeros

\begin{tabular}{|c|c|c|c|c|c|}
\hline \multirow[b]{2}{*}{ Dimension } & \multirow{2}{*}{ Criterion } & \multicolumn{2}{|c|}{ Participant's results } & \multicolumn{2}{|c|}{ Researchers' results } \\
\hline & & Items & Percentage (\%) & Items & Percentage (\%) \\
\hline \multirow{2}{*}{$\begin{array}{l}\text { Technical } \\
\text { features }\end{array}$} & Ease of use & $7 / 9$ & $77,7 \%$ & $8 / 9$ & $88,8 \%$ \\
\hline & Reliability & $2 / 5$ & $40 \%$ & $3 / 5$ & $60 \%$ \\
\hline \multicolumn{2}{|r|}{ Total } & $9 / 14$ & $59 \%$ & $11 / 14$ & $74,4 \%$ \\
\hline $\begin{array}{l}\text { Pedagogical contex- } \\
\text { tual characteristics }\end{array}$ & Contents quality & $3 / 5$ & $60 \%$ & $3 / 5$ & $60 \%$ \\
\hline \multicolumn{2}{|r|}{ Total } & $3 / 5$ & $60 \%$ & $3 / 5$ & $60 \%$ \\
\hline \multirow{5}{*}{$\begin{array}{l}\text { Communicative } \\
\text { approach-related } \\
\text { characteristics }\end{array}$} & Autonomy & $4 / 4$ & $100 \%$ & $4 / 4$ & $100 \%$ \\
\hline & $\begin{array}{l}\text { Language contex- } \\
\text { tualization }\end{array}$ & $6 / 7$ & $85,7 \%$ & $6 / 7$ & $85,7 \%$ \\
\hline & $\begin{array}{c}\text { Language skills } \\
\text { integration }\end{array}$ & $3 / 7$ & $42,8 \%$ & $3 / 7$ & $42,8 \%$ \\
\hline & Interculturality & $1 / 8$ & $12,5 \%$ & $1 / 8$ & $12.5 \%$ \\
\hline & Evaluation & $3 / 4$ & $75 \%$ & $3 / 4$ & $75 \%$ \\
\hline \multicolumn{2}{|r|}{ Total: } & $17 / 30$ & $63 \%$ & $17 / 30$ & $63,2 \%$ \\
\hline \multicolumn{2}{|r|}{ Final score: } & $29 / 49$ & $60,7 \%$ & $31 / 49$ & $65,8 \%$ \\
\hline
\end{tabular}




\section{Phase IV (quantitative stage)}

After the application (pilot testing) of the Checklist and the corresponding review of the Study Guide conducted by one of the participants of the target population, a 24-question evaluation survey was administered to her as a final stage of this research project (see Appendix B). This data-gathering instrument contained some of the questions that were also asked in the previous stage to the expert, so, it asked about the material's capacity to achieve impact on learners, to make them feel at ease, to develop their confidence, to be relevant and useful as well as to promote self-instruction. There were also 9 questions regarding the Checklist's overall structure, the clarity of its instructions and the quality of its descriptors and an additional set of 4 open-ended questions, which asked for the contributions, advantages, disadvantages and possible future use of this evaluation instrument.

The results from the survey indicated that both materials - the Study Guide and the Checklist met the objectives for which they were created, receiving a score of three or four points in each of the listed items (over a total of four points) (see Table 8). Thus, the former can contribute with augmenting the teachers' Knowing-how-to-do skill by providing theoretical and practical input for them to be aware about the several possibilities websites can offer for language students, as well as to know what to look for in these online materials when selecting the most appropriate one. Indeed, the respondent stated that the Guide serves as a starting point to venture in the digital world and bring it to the classroom setting, since she just started gaining knowledge and skills in the CALL evaluation field. On the other hand, the latter was regarded as a useful instructive tool that leads to reflect on one's own beliefs and opinions about the nature of the target language, language teaching and learning and the capacity of virtual spaces to support and enhance this process. It was highly valued (four points out of four) for not only focusing on the structural features of a website but also comprising aspects related to language learning and the students' active and constructive involvement while surfing on it, as reflected on the evaluation descriptors that account for the Communicative Approach principles.

Table 8: Participant's rating on Study Guide and Checklist

\begin{tabular}{|c|c|c|}
\hline Evaluation criteria & Given rating & General remarks from the participant \\
\hline \multicolumn{3}{|c|}{ STUDY GUIDE } \\
\hline Materials' impact & $\begin{array}{c}100 \% \\
\text { (4 points) } \\
\end{array}$ & \multirow{5}{*}{$\begin{array}{l}\text { - "como docente de inglés y que no he tenido la experi- } \\
\text { encia de enseñar español, la exploración de este sitio me } \\
\text { brindó herramientas para comenzar mi experiencia como } \\
\text { profe digital y desde luego, evaluar objetivamente los } \\
\text { recursos virtuales" (As an English teacher and I have not } \\
\text { had the experience of teaching Spanish, the exploration of } \\
\text { this site provided me with tools to start my experience as a } \\
\text { digital teacher and certainly, to objectively evaluate virtual } \\
\text { resources). } \\
\text { - "algunas de las ventajas de este material son: los con- } \\
\text { ceptos y la aclaración de dudas referentes al sitio web" } \\
\text { (some of the advantages of this material are the concepts } \\
\text { and clarification of doubts concerning the website). } \\
\text { - "las desventaja son: falta de tiempo para explorar este } \\
\text { sitio a cabalidad y asi emitir un mejor juicio valorativo" } \\
\text { (the drawbacks are lack of time to fully explore the web- } \\
\text { site and thus, to provide a better value judgement). }\end{array}$} \\
\hline $\begin{array}{c}\text { Teacher's development } \\
\text { of self-confidence }\end{array}$ & $\begin{array}{c}100 \% \\
(4 \text { points }) \\
\end{array}$ & \\
\hline Teacher's feeling at ease & $\begin{array}{c}100 \% \\
(4 \text { points }) \\
\end{array}$ & \\
\hline $\begin{array}{l}\text { Perception towards the } \\
\text { displayed contents as } \\
\text { relevant and useful }\end{array}$ & $\begin{array}{c}100 \% \\
\text { (4 points) }\end{array}$ & \\
\hline $\begin{array}{l}\text { Teacher's self- } \\
\text { investment }\end{array}$ & $\begin{array}{c}100 \% \\
(4 \text { points) }\end{array}$ & \\
\hline
\end{tabular}




\begin{tabular}{|c|c|c|}
\hline Evaluation criteria & Given rating & General remarks from the participant \\
\hline \multicolumn{3}{|c|}{ CHECKLIST MODEL } \\
\hline Structure & $\begin{array}{c}100 \% \\
(4 \text { points }) \\
\end{array}$ & \multirow{3}{*}{$\begin{array}{l}\text { - "sus fortalezas son: claridad de los descriptores, infor- } \\
\text { mación precisa y concisa. Volvería a utilizar este instru- } \\
\text { mento de evaluación con base a los criterios de este mate- } \\
\text { rial podré formar ideas and bases para mejorar mi proce- } \\
\text { so de evaluación de materiales de lengua" (its strengths } \\
\text { are the clarity of descriptor, the information is precise and } \\
\text { concise. I would use this evaluation instrument again and } \\
\text { based on the criteria displayed on this material, I will be } \\
\text { able to build ideas and fundaments to improve my process } \\
\text { of assessing language materials). } \\
\text { - "definitivamente los descriptores presentados son repre- } \\
\text { sentativos para esta medición porque nos orientan en el } \\
\text { proceso de evaluación de cada principio del enfoque co- } \\
\text { municativo" (definitely, the displayed descriptors are rep- } \\
\text { resentative for this measurement because they guide us in } \\
\text { the evaluation process of each principle of the Communi- } \\
\text { cative approach). }\end{array}$} \\
\hline Clarity of instructions & $\begin{array}{c}87.5 \% \\
(3 \text { points }) \\
\end{array}$ & \\
\hline $\begin{array}{l}\text { Quality of the evaluation } \\
\text { descriptors }\end{array}$ & $\begin{array}{c}100 \% \\
\text { (4 points) }\end{array}$ & \\
\hline
\end{tabular}

It is noteworthy that the main disadvantage found by the participant when evaluating the Spanish language-learning website was that it is time consuming exploring it as a whole, because in order to get an accurate judgment on its worth and quality it is advisable to follow every pathway and even solve most of its activities and exercises. Table 8 displays the overall results of both evaluated materials.

\section{Discussion}

The present study has given a first step toward providing an approach-based Checklist model proposal that guides teachers to make an informed decision on the most suitable Communicative language-learning websites, while at the same time they strengthened their Knowing-how-to-do skill. This was accomplished by conducting a four-phase research procedure from which findings suggested the following.

Primarily, it can be stated that the application of the Checklist to a selected language website and the usage of the Study Guide by one of the participants of the target population shed some light on the enhancement of her digital competence, mainly on the Knowing-how-to-do skill. Thus, it could be observed that the participant was able to make use of her critical and reflective abilities to appropriately addresses the evaluation of a website by judging its worth and suitability both quantitatively (i.e., numerical judgements) and qualitatively (i.e., open-ended commentaries). In fact, comparing the score she gave to the site, it can be evidenced that her ranking only differed in $5.1 \%$ from the researchers' appraisal, which demonstrated her capability to become a third-party evaluator (Levy \& Stockwell, 2006; Nomdedeu, n.d.) despite her lack of experience conducting this type of assessment and the short time given to do it.

On the other hand, the participant recognized how the theoretical insights provided by the Study Guide were of a great support not only to do the practical task (i.e., evaluate a website) but also to obtain a better understanding of websites technical language, allowing her to additionally, improve her Knowing learning domain that initially seemed to be shallow and limited (Lara, 2012). Hence, in a near future she might not probably have to base her decisions on an evaluation instrument but rely on her own practical and theoretical knowledge. 
Likewise, findings from pilot testing the proposed Checklist model showed that, in general, this instrument served as a starting point to (a) foster educators' coherence between the language learning theory in which they base their teaching and the online materials they implement in class; (b) locate the language websites that best encourage the development of the learners' communicative competence (Hassan \& Fakulti, 2011; Son, 2005; Susser, 2001; Yang \& Chan, 2008); and (c) enhance the Knowing-how-to do skill of the evaluator. Furthermore, this tool also attempted to enrich the teachers' practices by allowing them to identify which Low or High Order Thinking Skills will learners probably activate when surfing a language website (Campoverde, 2006), what is possible due to the nature of the evaluation descriptors presented in the Communicative approach dimension of the Checklist, even though this can only be evidenced by conducting a future empirical assessment (Chapelle, 2001; Reeder et al., 2004; Squires \& McDougall, 1996).

In respect to the overall results obtained by the Spanish website "Español para extranjeros" evaluated under the parameters of the Checklist model, it demonstrated to be a well-founded site, with no large structural failures, that bases its instruction on communicative language learning principles up to the level that its internal properties allow. Clearly, its designers were aware of providing users with material that goes beyond the traditional focus on forms associated with authoring programs and, conversely, seeks to encourage learners to use the target language to produce and negotiate meanings (Brown, 1994), even if it implies proposing printable resources for classroom use. Therefore, by incorporating elements such as multimedia, hypertextuality and hypermedia, this website manages to offer meaningful and contextualized input that promotes learner-centered processes and fosters the practice of receptive skills while delivering immediate feedback that leads to self-monitoring of learning performance.

However, it should be noted that these types of quality websites are difficult to find due to the hardware requirements, the time investment and the expertise of its creators in the language field; thus, for example, it needs to be designed by a group of interdisciplinary experts such as philologists, language teachers and computational linguists, who truly understand the learners' communicative needs and interests (Cruz, 2003; Torat, 2000), and not just allocate this task to web programmers.

From the above presented, it can be inferred that this research project implied on the one side, a theoretical importance as it contributed to the growing literature on the CALL evaluation area, specifically, on the assessment of online materials based upon the Communicative teaching approach principles because, unlike what most educators might think, a quality website cannot be defined solely on its apparent interactivity and provision of structuralist input. On the other side, it represented a practical relevance since its derived products, that is, the Checklist model and the Study guide, attempted to assist and guide educators in their pursuit of finding suitable and reliable materials that enhance learning processes while they gain expertise on this field. In this regards, for instance, the instrument can be adapted to evaluate e-Learning environments owing to most of its components (i.e., evaluation criteria and descriptors) being applicable to any online material and serves as well as a reference to create or improve the own setting; likewise, the instructional material for being information-rich, can be used by anyone who wants to augment his/her knowledge on technical language.

Finally, even with the present study serving as a cornerstone, there is still a need for further research in the fields of CALL evaluation and Digital competence enhancement; thereby, some recommendations on this respect include the following: (a) the study of students' learning outcomes after having used Communicative-based language websites, by conducting an empirical evaluation; (b) the assessment of an e-learning environment using the proposed Checklist model in order to judge the extent to which it truly fosters a communicative and meaningful languagelearning process; (c) the updating or revision of the different Checklist's elements in the light of 
emerging language teaching approaches and the technological advancements in learning online materials; and (d) the development of instructional materials that seek to strengthen the language teachers' digital competence in its all learning domains, that is, the Knowing, Knowing-how-tobe and the Knowing-how-to do. Additionally, for upcoming projects based on a similar concern, a larger population size and a broader panel of experts should be included with the aim of having more robust data to analyze and thus to demonstrate higher levels of reliability and validity in findings.

\section{Conclusion}

The findings provided a more comprehensive picture of what to focus on when evaluating CALL materials and what are the possible benefits for the evaluator when embarking on this task. Thus, with the Checklist model and the Study Guide proposed as a result of this research project, language teachers are able to relieve the heavy burden they have in regards to selecting and integrating quality and suitable online materials that meet their communicative teaching objectives. Moreover, by getting involved in the evaluation process, the educators have the opportunity to continuously gain expertise on their practical skills and augment their technological knowledge.

Ultimately, this represents a win-win for the language teacher and student, as the former can speed up the search of appropriate learning virtual environments while enhancing their Knowinghow-to-do learning domain as part of their Digital competence, and the latter can profit from practicing the target language by means of supporting material that is eye-catching, motivating, easy to manage, reliable and that additionally, encourages to a higher extent communicative principles such as the autonomy, language contextualization, integration of the four language skills, interculturality and evaluation.

\section{Acknowledgements}

We appreciate the contribution of Prof. Ana Maria Rojas Fierro for guiding researchers on the development of this study as well as the participants and language-teaching experts who also contributed with their suggestions and opinions. Additionally, we wish to acknowledge the input of participants at the International Conference ICT for Language Learning, where a shorter version of this document was presented and, finally, recognize the valuable feedback provided by the editor and peer reviewers of the IJELL Journal.

\section{References}

Adell, J. (1995). La navegación hipertextual en el World Wide Web: Implicaciones para el diseño de materiales educativos [Hypertext browsing in the World Wide Web: Implications for the design of educative materials]. II Congreso de Nuevas Tecnologías de la Información y Comunicación para la Educación, Palma de Mallorca, Spain. Retrieved from http://nti.uji.es/docs/nti/edutec95.html

Anderson, L., \& Krathwohl, D. (2001). Taxonomy for learning, teaching and assessing: A revision of Bloom's Taxonomy of Educational Objectives. New York: Longman.

Aly, M. (2008). An evaluative study of some online websites for learning and teaching English as a foreign language. Retrieved from http://files.eric.ed.gov/fulltext/ED499586.pdf

Area, M. (2009). Introducción a la tecnología educativa [Introduction to educational technology]. Manual Electrónico. Retrieved from https://campusvirtual.ull.es/ocw/file.php/4/ebookte.pdf

Campoverde, A. (2006). Guía de evaluación de educación inicial [Evaluation guide for initial education]. Retrieved from http://es.slideshare.net/luztejerina/guia-de-evaluacion-13641961

Canale, M., \& Swain, M. (1980). Theoretical bases of communicative approaches to second language teaching and testing. Applied Linguistics, 1, 1-47. 
Caridad, E. (2008). Características de los materiales web para la enseñanza y aprendizaje de lenguas extranjeras [Characteristics of web materials for teaching and learning foreign languages]. Revista de Medios y Educación, (31), 31-38. Retrieved from http://www.redalyc.org/articulo.oa?id=36803103

Chamorro, M. (2009). Integración de destrezas en niveles iniciales [Integration of skills in starting levels]. MarcoELE, (9), 33-52. Retrieved from http://marcoele.com/descargas/expolingua1996-chamorro.pdf

Chapelle, C. (2001). Computer applications in second language acquisition: Foundations for teaching, testing, and research. Cambridge: Cambridge University Press.

Chapelle, C., \& Hegelheimer, V. (2004). The English language teacher in the 21 st century. In S. Fotos \& C. Browne (Eds.), New perspectives in CALL for second language classrooms (pp. 299-316). Mahwah, NJ: Erlbaum.

Chuo, S-C., \& Kung, T-H. (2002). Students' perceptions of English learning through ESL/EFL Websites. TESL-EJ, 6(1). Retrieved from http://www-writing.berkeley.edu/TESL-EJ/ej21/a2.html

Codina, L. (2000). Evaluación de recursos digitales en línea: Conceptos, indicadores y métodos [Evaluation of online digital resources: Concepts, indicators and methods]. Revista española de documentación cientifica, 23(1), 9-44. doi: 10.3989./2000.v23.il.315.

Colpaert, J. (2004). Editorial: Transdisciplinarity. Computer Assisted Language Learning, 17(5), 459-472.

Cruz, M. (2002). Materiales para la ELE en internet: Análisis de 207 webs útiles para la enseñanza del ELE [SFL materials on the Internet: Analysis of 207 useful websites for SFL teaching]. In M. Cruz. Enseñar español en la era de la internet. La WWW y la enseñanza del español como lengua extranjera (pp. 97-154). Barcelona, Spain: Octaedro.

Cruz, M. (2003). Presencia (y ausencia) de los hipermedios y de los géneros electrónicos en las Webs para la enseñanza-aprendizaje del español como lengua extranjera (ELE) [Presence (and absence) of hypermedia and electronic genres in the Web in teaching-learning Spanish as a foreign language (SFL)]. $C$ \& E: Cultura y educación, 15(3), 311-325.

Díaz, C., \& Moncada, S. (2014). Evaluación y selección de sitios web coherentes con el enfoque comunicativo para el aprendizaje de ELE (Master dissertation) [Evaluation and selection of SFL learning websites coherent with the communicative approach]. Colombia, Pontificia Universidad Javeriana. Retrieved from http://repository.javeriana.edu.co/bitstream/10554/15959/1/DiazRomeroAndreaCarolina2014.pdf

Duignan, P. (2003). Approaches and terminology in programme and policy evaluation: A New Zealand Reader. In N. Lunt, C. Davidson, \& K. McKegg (Eds.), Evaluating policy and practice. Auckland, New Zealand: Pearson Education.

European Parliament and European Council. (2007). Key competences for lifelong learning - A European framework. Retrieved from http://www.alfa-trall.eu/wp-content/uploads/2012/01/EU2007keyCompetencesL3-brochure.pdf

Fernández, E. (2007). Las TIC en la clase de ELE. Interculturalidad y desarrollo afectivo. Propuesta de una Unidad Didáctica TIC para un aula de enseñanza de ELE afectivamente eficaz (Master dissertation) [ICT in the SFL class. Multiculturalism and emotional development. Proposal for an ICT didactic unit for an effective SFL classroom teaching]. Internacional Menéndez Pelayo University, Madrid, España.

Fernández, S. (1988). Corregir y evaluar desde una perspectiva comunicativa [Correct and evaluate from a communicative perspective]. Actas I de las primeras jornadas pedagógicas de ASELE, 13-28. Retrieved from http://cvc.cervantes.es/ensenanza/biblioteca ele/asele/pdf/01/01 0017.pdf

Ferrari, A. (2013). DIGCOMP: A framework for developing and understanding digital competence in Europe. European Commission. Retrieved from http://ftp.jrc.es/EURdoc/JRC83167.pdf

Fotos, S., \& Brown, C. (2004). New perspectives on CALL for second and foreign language classrooms. Mahwah, NJ: Lawrence Erlbaum Associates. 
García, G. (2000). La ruta de la lengua española (una Web para la enseñanza-aprendizaje del español como lengua extranjera) (Master dissertation) [La ruta de la lengua española (a Website for teachinglearning Spanish as foreign language)]. Salamanca University, Salamanca, Spain.

Gonzalo, C. (2006). Tipología y análisis de enlaces web: aplicación al estudio de los enlaces fraudulentos y de las granjas de enlaces [Typology and analysis of web links applied to the study of fraudulent links and link farms]. Textos universitaris de biblioteconomia i documentació, (16). Retrieved from http://bid.ub.edu/pdf/16gonza2.pdf

Instituto Cervantes. (2012). Las competencias clave del profesorado de lenguas segundas y extranjeras [Key competencies of second and foreign language teachers]. Retrieved from http://cfp.cervantes.es/imagenes/File/competencias_profesorado.pdf

Hassan, H., \& Fakulti, B. (2011). The criteria of language learning website. Retrieved from http://eprints.utm.my/11971/1/The_Criteria_Of_Language_Learning_Website.pdf

Hernández, R., Fernández, C., \& Baptista, P. (2006). Recolección y análisis de los datos cualitativos [Collection and analysis of qualitative data]. In R. Hernández, C. Fernández y P. Baptista (Eds.), Metodología de la investigación (pp.581-684). México: McGraw-Hill Interamericana.

Higueras, M. (2010). Criterios para la elaboración y selección de actividades comunicativas con internet [Criteria for the preparation and selection of communicative activities with Internet]. MarcoELE (10), 109-121. Retrieved from http://marcoele.com/descargas/expolingua 2002.higueras.pdf

Hita, G. (2004). La enseñanza comunicativa de idiomas en internet. Características de los materiales y propuesta didáctica [Communicative language teaching on the Internet. Characteristics of materials and didactic proposal]. Red Electrónica de Didáctica del Español como Lengua Extranjera, (2). Retrieved from http://www.mecd.gob.es/dctm/redele/MaterialRedEle/Biblioteca/2004_BV_02/2004_BV_02_12Hita.pdf?documentId=0901e72b80e412c3

Hubbard, P. (1996). Elements of CALL methodology: Development, evaluation, and implementation. In M. Pennington (Ed.), The power of CALL (pp.15-33). Bolsover, TX: Athelstan.

Hubbard, P. (2003). A survey of unanswered questions in CALL. Computer Assisted Language Learning, 16(2-3), 141-154.

Hubbard, P. (2006). Evaluating CALL software. In L. Ducate \& N. Arnold (Eds.), Calling on CALL: From theory and research to new directions in foreign language teaching (pp.1-26). San Marcos, Texas: CALICO.

Kartal, E. (2005). The Internet and autonomous language learning: A typology of suggested aids. The Turkish Online Journal of Educational Technology, 4(4), 54-58.

Kartal, E., \& Uzun, L. (2010). The Internet, language learning, and international dialogue: Construction online foreign language learning websites. Turkish Online Journal of Distance Education-TOJDE, 11(2), 90-107.

Kelley, L. (1999). Measurement made accessible: A research approach using qualitative, quantitative and quality improvement methods. California: SAGE publications.

Knowles, J. (1992). Models for understanding pre-service and beginning teachers' biographies: Illustrations from case studies. In I. Goodson (Ed.), Studying teachers' lives (pp. 99-152). New York: Teachers College Press.

Lara, T. (2012). Alfabetizar en la cultura digital [Literacy in the digital culture]. In T. Lara, F. Zayas, N. Arrukero \& E. Larequi (Eds.), La competencia digital en el área de lengua (pp.9-23). Barcelona: Octaedro.

Lázaro, O. \& Fernández, J. (2000). Criterios de evaluación de materiales en la red: alumnos y usuarios de E/LE [Evaluation criteria of web-materials: SFL students and users]. Cuadernos Cervantes, 28. Retrieved from http://marcoele.com/descargas/expolingua1996 lozano-ruiz.pdf 
Levy, M. \& Stockwell, G. (2006). Evaluation. In M. Levy \& G. Stockwell (Eds.), CALL dimensions: Options and issues in Computer-Assisted Language Learning (pp.40-83). Mahwah, New Jersey: Lawrence Erlbaum Associates, Inc.

Lion, C. (2012). Desarrollo de competencias digitales para portales de la región [Development of digital skills for portals in the region]. Retrieved from http://www.relpe.org/wp-content/uploads/2013/04/09Desarrollo-de-CompetenciasDigitales-para-Portales-de-la-Regi\%C3\%B3n.pdf

Liu, M. (1994). Hypermedia assisted instruction and second language learning: A semantic-networked based approach. In M. Reed, J. Burton \& M. Liu (Eds.), Multimedia and megachange: New roles for educational computing (pp. 293-312). Binghamton, United States: The Haworth Press.

Liu, G., Liu, Z., \& Hwang, G. (2011). Developing multi-dimensional evaluation criteria for English learning websites with university students and professors. Computers \& Education, 56(1), 65-79.

Lobin, H., \& Rösler, D. (2012). Tutoring system and computers-assisted language learning (CALL). In A. Mehler, \& L. Romary (Eds.), Handbook of technical communication (pp.571-589). Berlin, Germany: Mouton de Gruyter.

Lozano, G., \& Ruiz Campillo, P. (2009). Criterios para el diseño y la evaluación de materiales comunicativos [Criteria for the design and evaluation of communicative materials]. MarcoELE (9), 127-155. Retrieved from http://marcoele.com/descargas/expolingua1996 lozano-ruiz.pdf

Luzón, J., \& Soria, I. (1999). El enfoque comunicativo en la enseñanza de lenguas. Un desafío para los sistemas de enseñanza y aprendizaje abiertos y a distancia [The communicative approach to language teaching. A challenge for education systems and open and distance learning]. Revista iberoamericana de educación a distancia, 2(2), 63-92. Retrieved from http://dialnet.unirioja.es/servlet/articulo?codigo $=318951$

Ma, Q. (2008). Empirical CALL evaluation: The relationship between learning process and learning outcome. CALICO Journal 26(1), 108-122.

Magnúsdóttir, S. (2010). Internet en la enseñanza del español como lengua extranjera: posibilidades y retos en su aplicación en el aula (Undergraduate dissertation) [Internet in teaching Spanish as a foreign language: opportunities and challenges in its application in the classroom]. Islandia University, Reikiavik, Islandia. Retrieved from http://skemman.is/stream/get/1946/4202/12112/1/2_fixed.pdf

Mangenot, F. (1998). Classification des apports d'Internet à l'apprentissage des langues [Classification of the Internet contribution to language learning]. ALSIC, 1(2), 133-146. Retrieved from http:/hal.inria.fr/docs/00/00/16/95/PDF/alsic_n02-pra1.pdf

Mantilla, M. (n.d.). Interactividad o repetición. Trabajo Final del programa FONTE Formación Online de Tutores de Español de AulaDiez [Interactivity or repetition. Final work of the FONTE Online Spanish tutor training program of AulaDiez]. Retrieved from http://www.auladiez.com/didactica/FONTETrabajoFinalMargaritaMantillaDiaz.pdf

Mao, P., \& Kung, S. (2001). ¿A lo virtual? ¿A lo real? Internet aplicada a la enseñanza de la gramática de E/LE [Virtual? Real? Internet applied to the SFL grammar teaching]. XII congreso internacional de ASELE, 567-575. Retrieved from http://cvc.cervantes.es/ensenanza/biblioteca_ele/asele/pdf/12/12 0567.pdf

Marquès, P. (1999). Criterios para la clasificación y evaluación de espacios web de interés comunicativo [Criteria for classification and evaluation of communicative web spaces]. Educar (25), 95-111. Retrieved from http://www.raco.cat/index.php/educar/article/viewFile/20717/20557

Melero, P. (2004). De los programas nocional-funcionales a la enseñanza comunicativa [From notiofunctional programs to communicative teaching]. In J. Sánchez \& I. Santos (Eds.), Vademécum para la formación de profesores. Enseñar español como segunda lengua (L2)/lengua extranjera (LE) (pp. 689-714). Madrid: Sociedad general española de librería, S.A.

Mishan, F. (2013). Modes of delivery. In B. Tomlinson (Ed.). Applied linguistics and material development (pp. 287-301). London: Bloomsburry Linguistics. 
Nomdedeu, A. (n.d). Actualización de los recursos del docente de ELE en Internet [The updating of SFL teachers resources on the Internet]. redELE, (12), 1-23. Retrieved from http://www.mecd.gob.es/dctm/redele/Material-RedEle/Revista/2008_12/2008_redELE_12_06Nomdedeu.pdf?documentId=0901e72b80de14e5

Patton, M. (1990). Qualitative evaluation and research methods. Newbury Park: SAGE Publishers.

Plass, J. (1998). Design and evaluation of the user interface of foreign language multimedia software: A cognitive approach. Language Learning \& Technology, 2(1), 35-45.

Reeder, K., Heift, T., Roche, J., Tabyanian, S., Schlickau, S., \& Golz, P. (2004). Toward a theory of evaluation for second language learning media. In S. Fotos \& C. Browne (Eds.), New perspectives on CALL for second language classrooms (pp.255-278). Mahwah, NJ: Lawrence Erlbaum Associates, Inc.

Richards, J., \& Rodgers, T. (1986). Approaches and methods in language teaching. Cambridge, UK: Cambridge University Press.

Robb, T., \& Susser, B. (2000). The life and death of software. CALICO Journal, 18(1), 41-52.

Rodríguez, J. (2004). El uso de Internet en el aula de ELE [The Internet use in the SFL classroom]. Revista electrónica de didáctica español lengua extranjera, (2). Retrieved from http://www.mecd.gob.es/dctm/redele/MaterialRedEle/Revista/2004_02/2004_redELE_2_14Rodriguez.pdf?documentId=0901e72b80e06a65

Rodríguez, E. (2012). Guía para la construcción de indicadores de gestión [Guide to building management indicators]. Retrieved from http://portal.dafp.gov.co/portal/pls/portal/formularios.retrive publicaciones?no=1595

Rubio, D., Berg-Weger, M., \& Tebb, S. (2003). Objectifying content validity: Conducting a content validity study in social work research. Social Work Research, 27(2), 94-104.

Seliger, H. \& Shohamy, E. (1989). Second language research methods. Oxford, UK: Oxford University Press.

Squires, D., \& McDougall, A. (1996). Software evaluation: A situated approach. Journal of Computer Assisted Learning, 12(3), 146-161.

Son, J.-B. (2005). Exploring and evaluating language learning Web sites. In J.-B. Son \& S. O'Neill (Eds.), Enhancing learning and teaching: Pedagogy, technology and language (pp. 215-227). Flaxton, Australia: Post Pressed. Retrieved from https://eprints.usq.edu.au/820/1/Son_ch13 2005.pdf

Stoker, D., \& Cooke, A. (1994). Evaluation of networked information sources. In A. H. Heal \& J. W. Weiss (Eds.), Information superhighway: The role of librarians, information scientist and intermediaries. Proceedings of the 17th International Essen Symposium 24th - 27th October 1994. Retrieved from http://users.aber.ac.uk/das/texts/eval.htm

Susser, B. (2001). A defense of checklists for courseware evaluation. ReCALL 13(2), 261-276.

Tashakkori, A. \& Teddlie, C. (2003). The past and future of mixed methods research: From data triangulation to mixed model design. In A. Tashakkori \& C. Teddlie (Eds.), Handbook of mixed methods in social and behavioral research (pp. 671-702). Thousand Oaks, CA: Sage.

Tomlinson, B. (2011). Introduction: Principles and procedures of material development. In B. Tomlinson (Ed.), Materials development in language teaching (pp.1-26). Cambridge: Cambridge University Press.

Torat, B. (2000). Computer-assisted language learning: An overview. Thailand-Australia Science \& Engineering Project (TASEAP). Retrieved from http://web.warwick.ac.uk/CELTE/tr/ovCALL/taseapCALL.pdf

Vela, J. (n.d.). Criterios e indicadores para una evaluación en educación -educación para adultos- [Evaluation criteria and indicators for education -adult education-]. Retrieved from http://www.redescepalcala.org/inspector/DOCUMENTOS\%20Y\%20LIBROS/EVALUACION/CRITERIOSINDICADORES.doc 
Warschauer, M., Shetzer, H., \& Meloni, C. (2000). Internet for English teaching. Virginia, USA: Teachers of English to Speakers of Other Languages, Inc.

Yang, Y., \& Chan, C. (2008). Comprehensive evaluation criteria for English learning websites using expert validity surveys. Computers \& Education (51), 403-422. Retrieved from

http://proj.ncku.edu.tw/research/articles/e/20071130/5.html 


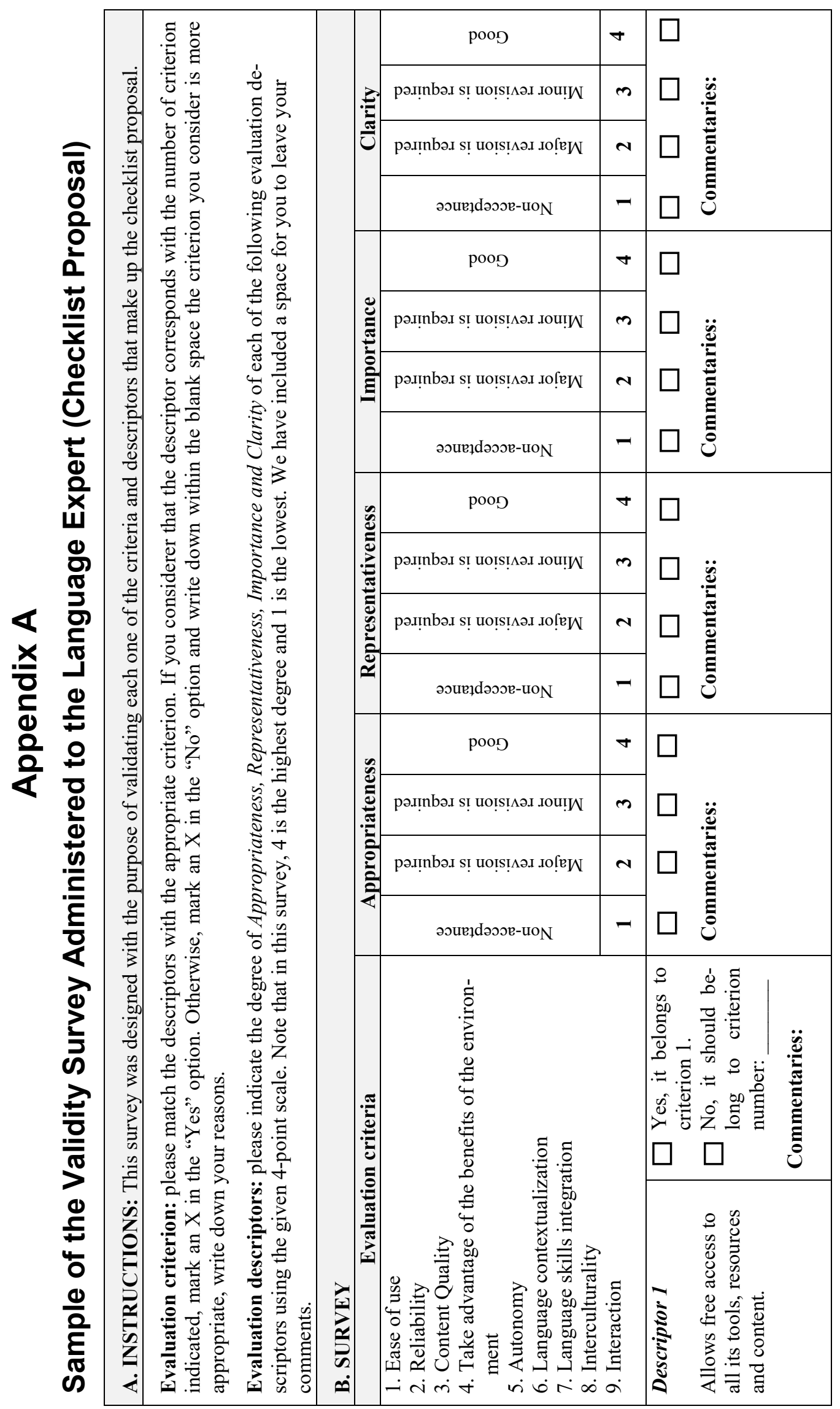




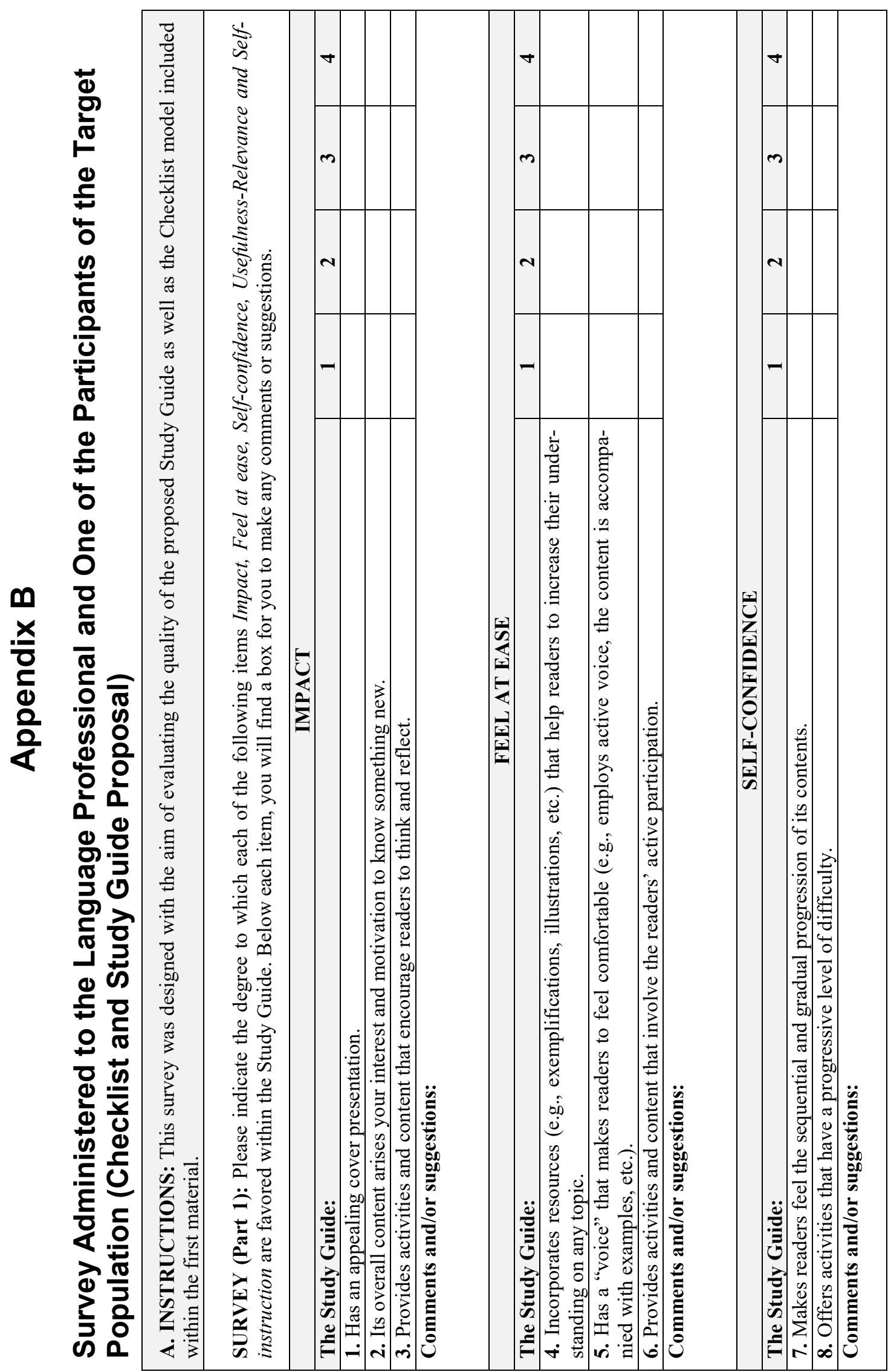




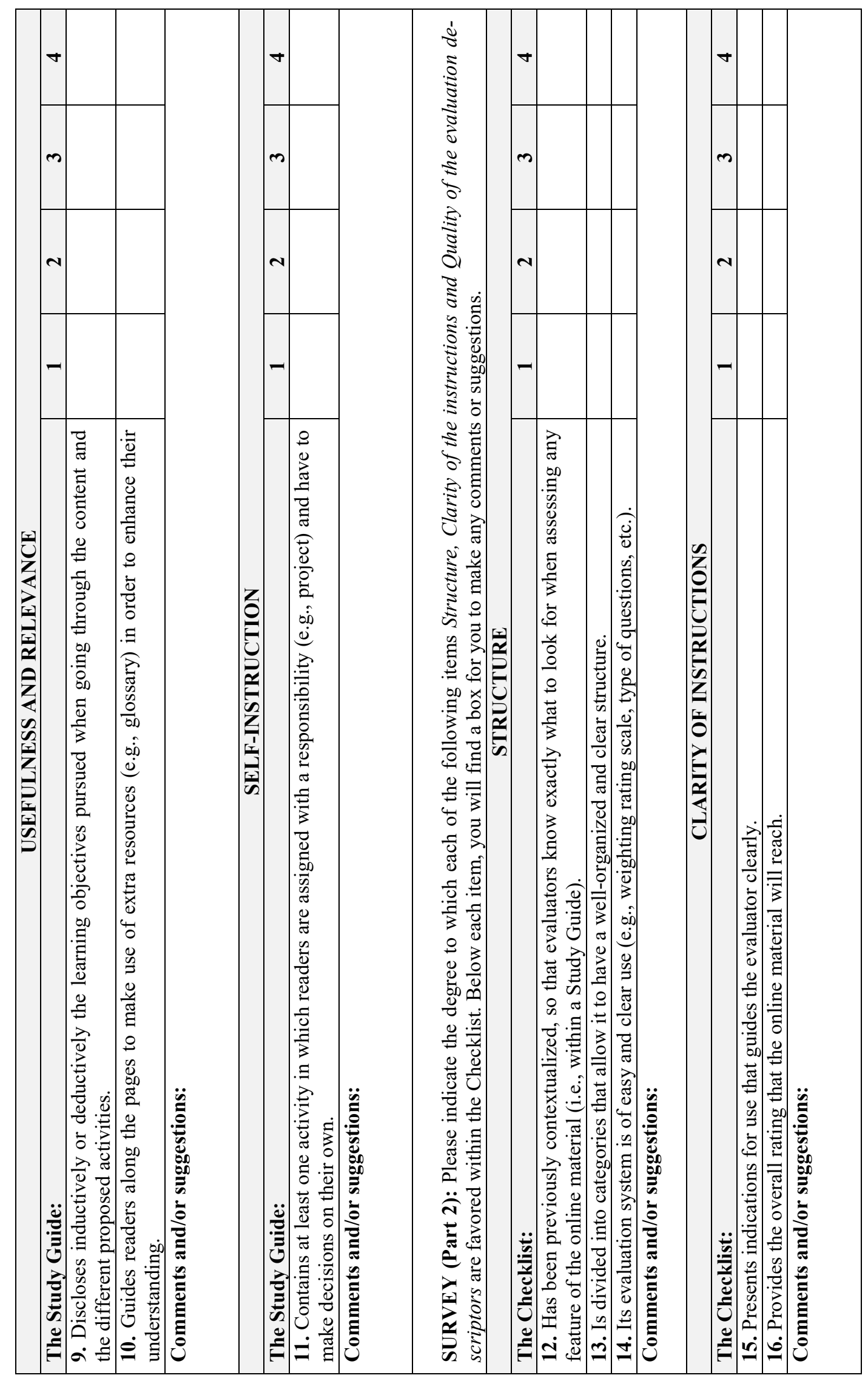



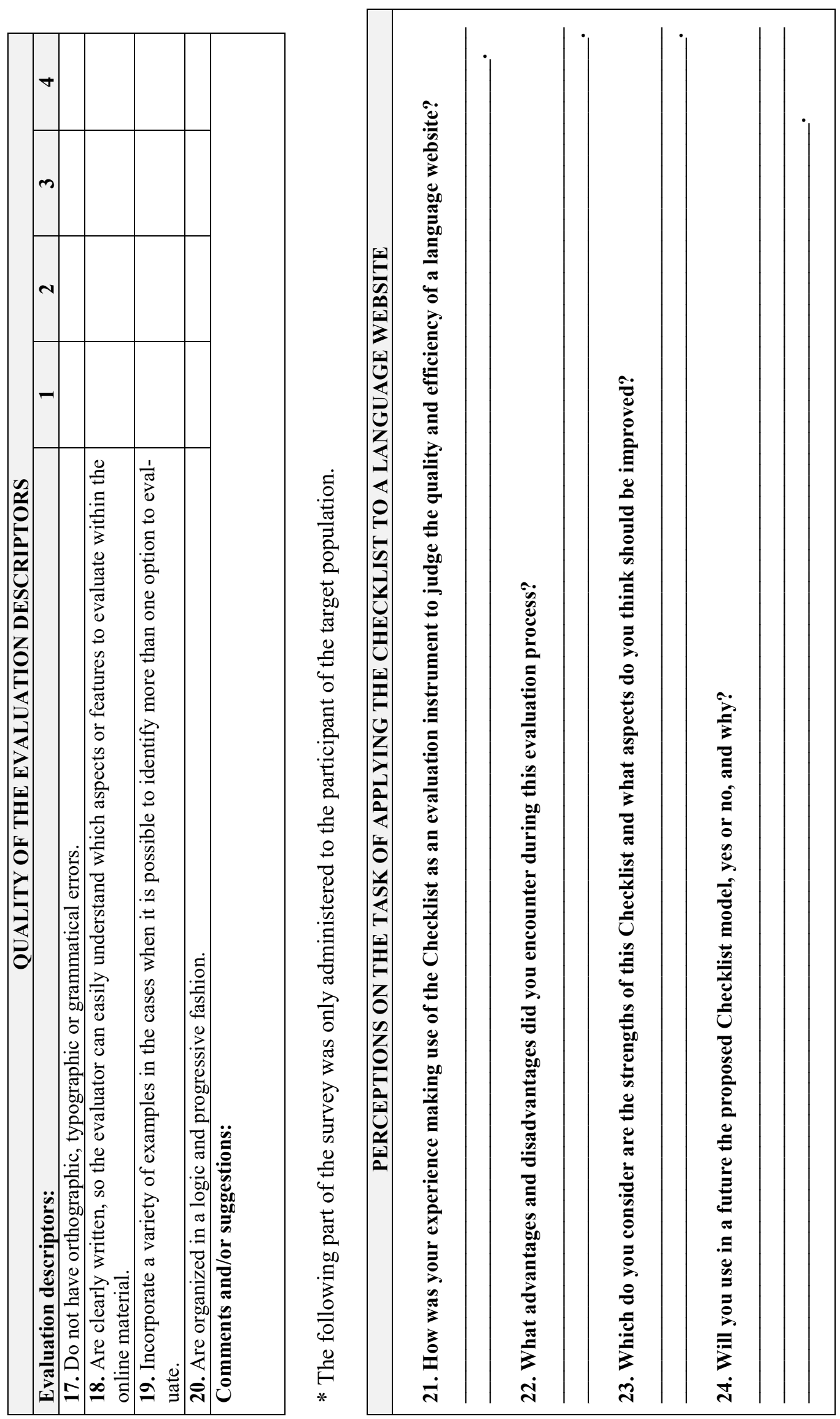


\section{Appendix C}

\section{Evaluation Language-Learning Websites Checklist}

The checklist below consists of three main dimensions that encompass technical characteristics (ease of use and reliability), contextual-pedagogical characteristics (content quality) and features related to the Communicative Approach principles (autonomy, language contextualization, language skills integration, interculturality, interaction and evaluation). It is noteworthy that descriptors involving the last assessing dimension were written in relation to the possibilities provided by the website in terms fostering learners' low or high order thinking skills as well as boosting their communicative competence.

It is advisable to skim first this evaluation instrument before applying to a chosen language website. Additionally, the evaluator has to keep in mind that even though the checklist was mainly designed to provide insights on the Communicative Approach principles reflected on websites, it still allows teachers to glimpse its strengths in relation to other presented criteria.

Instructions: Mark with an " $X$ " the column that best reflects the language website's quality in relation to the proposed evaluation criteria and descriptors.

\begin{tabular}{|c|c|c|}
\hline \multicolumn{3}{|l|}{ TECHNICAL CHARACTERISTICS } \\
\hline \multicolumn{3}{|l|}{ EASE OF USE } \\
\hline The website: & YES & NO \\
\hline 1. Allows free access to all the tools, resources and content. & & \\
\hline $\begin{array}{l}\text { 2. Provides use specifications related to the hardware (e.g., processor, sound card, internet } \\
\text { connection, etc.) and software requirements (e.g., Web browser such as Internet Explorer, } \\
\text { Google Chrome, Mozilla, etc.). }\end{array}$ & & \\
\hline $\begin{array}{l}\text { 3. Includes a navigation guide/site map that ensures accessibility to the user and provides a } \\
\text { general visual schema of the available contents. }\end{array}$ & & \\
\hline $\begin{array}{l}\text { 4. Includes frames that enable the permanent view of the index sections (e.g., menu, grammar, } \\
\text { exercises, culture, etc.) and therefore, facilitates the transition between pages. }\end{array}$ & & \\
\hline $\begin{array}{l}\text { 5. Provides a clear and simple language, which allows a general understanding for users of } \\
\text { different language levels. }\end{array}$ & & \\
\hline $\begin{array}{l}\text { 6. Uses a range of colors that do not fatigue or irritates the users' view and therefore, it is } \\
\text { attractive and motivating to navigate. }\end{array}$ & & \\
\hline 7. Has a balance between the textual and multimedia content. & & \\
\hline $\begin{array}{l}\text { 8. Respects the conventions of the virtual environment by underlying links in blue and pre- } \\
\text { senting the information following the multimedia mesh. }\end{array}$ & & \\
\hline $\begin{array}{l}\text { 9. Has graphic consistency between the font sizes for titles, subtitles and text body, and icon } \\
\text { buttons are always the same. }\end{array}$ & & \\
\hline \multicolumn{3}{|l|}{ Commentaries: } \\
\hline \multicolumn{3}{|l|}{ RELIABILITY } \\
\hline The website: & YES & NO \\
\hline 10. Is periodically updated (e.g., date of last update; lin & & \\
\hline
\end{tabular}


11. Provides information on the author(s) or the source of creation by means of links with labels such as Who are we? About us, consultations, copyright or simply " $u$ s".

12. Offers information on the teaching and/or learning theory on which it is based on.

13. Is backed up by a person or a team of professionals in the language-teaching field.

14. Does not contain spelling, typographical or grammatical errors.

\section{Commentaries:}

\section{CONTEXTUAL PEDAGOGICAL CHARACTETISTICS}

\section{CONTENT QUALITY}

The website:

15. Indicates the language level skills expected to attain when solving each of the given activities and exercises.

16. Integrates a variety of contents, activities and resources.

17. Includes the learning objectives pursued in the development of a particular activity or exercise.

18. Contains short and comprehensible instructions that guide the development of the proposed activities and exercises.

19. Sets out grammar in functional terms, that is from the perspective of how it creates and expresses meaning (e.g,. introducing oneself in order to work on the "verb to be" grammar topic).

\section{Commentaries:}

AUTONOMY

\section{COMMUNICATIVE APPROACH-RELATED CHARACTERISTICS}

The website allows learners to:

20. Find texts and resources of their choice by integrating hyperlinks that link words to input such as readings, videos, pictures, sounds, exercises, etc.

21. Make different learning routes in and outside of its structure by providing hyperlinks and an internal searching box.

22. Build their own learning pathways after taking a diagnostic and/or placement test.

23. Monitor their learning process by solving language exercises or activities and clicking on the "check" option button.

\section{Commentaries:}

\section{LANGUAGE CONTEXTUALIZATION}

The website allows learners to:

24. Inductively infer the uses of certain grammatical forms by providing input enhancement (e.g., capital letter, boldface, underlining, italics, etc.).

25. Interpret within a text the meaning of unknown words or expressions by offering the support of linguistic resources such as dictionaries or clicking on buttons that display the definition in written or drawn form. 
26. Understand written and oral sentences by offering activities and exercises that lead them to reach a functional purpose within the language.

27. Inductively contrast the use of linguistic forms of the different target-language variants by the exposure to authentic input in or outside its structure.

28. Make predictions in relation to the content of a text by means of written or oral multimedia elements such as images, videos and audios.

29. Use different groups of lexical units to solve activities or exercises that comprise a communicative purpose (e.g., planning a party).

30. Rank the quality of the site and its contents (e.g., grammatical explanations, exercises, multimedia resources, etc.) by some of the following means: a mailbox of comments or recommendations, a feedback comments box, a "contact us" bottom, etc.

\section{Commentaries:}

\section{LANGUAGE SKILLS INTEGRATION}

\begin{tabular}{|l|l|l|}
\hline The website allows learners to: & YES & NO
\end{tabular}

31. Find oral or written texts according to their interests and communicative needs by redirecting to external sites (e.g., newspapers, magazines, shows, documentaries, live streaming radio or television, etc.).

32. Recognize in oral or written texts the main ideas and details by presenting activities or exercises that favor the understanding of authentic materials (documentaries, podcasts, trailers, poems, stories, etc.).

33. Identify prosodic features (e.g., intonation, accent, pauses, tone, etc.) coming from the communicative intention of characters in a video internally hosted or linked to other site.

34. Recognize samples of authentic sounds through songs, dialogs of everyday life, audiobooks, etc. that provide a variety of communicative contexts.

35. Self-monitoring their listening and reading comprehension skills by including activities that encompass authentic uses of the target language (e.g., dialogues, news reports, etc.).

36. Check their oral comprehension by clicking on the transcription button for video or audio.

37. Carry out oral and written activities that imply a communicative purpose by offering rich input (e.g., journals, videos, recordings, etc.) and encouraging input elaboration.

\section{Commentaries:}

\section{INTERCULTURALITY}

\section{The website allows learners to:}

38. Identify the cultural traits of the different speaking regions of the target language through the inclusion of texts and resources that address sociocultural knowledge issues (e.g., daily life, conditions of life, values, beliefs, social conventions, ritual behavior, etc.) and therefore, prevents stereotyped attitudes.

39. Recognize elements of non-verbal communication of the target culture in videos in which paralinguistic features can be easily evidenced (e.g., body language, gestures, facial expressions, tone and pitch of voice, etc.).

40. Compare cultural traits of various speaking regions of the target language by integrating topics of cultural interest that have influenced people's lives (e.g., popular culture, politics, history, etc.). 
41. Contrast elements of their culture with those of the target language by providing videos, audios or readings that encompass linguistic variations (e.g., diatopic, diastratic and diaphasic).

42. Interact with other users using synchronous (e.g., chat, instant messages) and/or asynchronous (e.g., email, forum, newsgroups, distribution lists, etc.) $\mathrm{CMC}$ tools hosted within the site or linked to other ones.

43. Post their opinion on any topic and get to know others' by taking surveys and/or participating in a voting activity.

44. Generate attitudes of openness and empathy towards the target culture by including texts, readings and/or videos that address issues such as immigration, political debates and the different standpoints, human rights, among others.

45. Generate collaborative learning in real contexts of communication (e.g., forums, discussion boards, etc.).

\section{Commentaries:}

\section{EVALUATION}

The website allows learners to:

46. Recognize their level of accomplishment in relation to the intended communicative objectives through the inclusion of any of these means: evaluation rubrics or phrases referring to what the student has been able to achieve when solving an activity or exercise.

47. Identify in a particular exercise or activity their right answers and correct the errors by clicking on the auto-feedback button (e.g., delete the incorrect answers, indicate the percentage of hits or include an explanatory comment).

48. Find and correct errors in oral and written comprehension activities that may affect communication, this by offering a feedback button where understanding is favored (e.g., automatically delete wrong answers that transgress the message).

49. Deduct the possible answer(s) of an exercise by giving an explanatory hint.

Commentaries:

Total number $=$

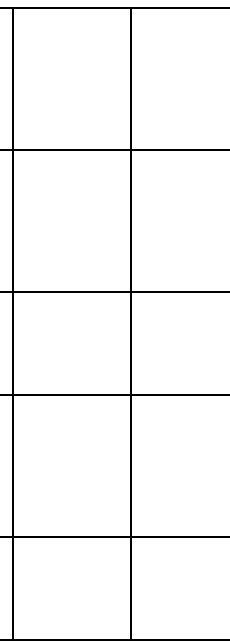

aries:

Once the grid has been filled, the evaluator can proceed to count out the number of YES entries related to the Communicative approach dimension, taking into account that it involves a total of 30 evaluation descriptors. The following chart displays the degree of qualification achieved by the website in regards to this specific language teaching approach:

\begin{tabular}{|c|c|}
\hline $\begin{array}{c}\text { Number of X entries in the "Yes" column } \\
\text { (Communicative Approach) }\end{array}$ & Degree of qualification \\
\hline $\begin{array}{c}\text { Between } 1 \text { and } 7 \\
\text { (Between } 1 \% \text { and } 25 \%)\end{array}$ & Poor (Not appropriate) \\
\hline $\begin{array}{c}\text { Between } 8 \text { and } 15 \\
\text { (Between } 26 \% \text { and } 50 \%)\end{array}$ & Suitable (acceptable with reservations) \\
\hline $\begin{array}{c}\text { Between } 16 \text { and } 22 \\
\text { (Between } 51 \% \text { and } 75 \%)\end{array}$ & Good (appropriate for use) \\
\hline $\begin{array}{c}\text { Between } 23 \text { and } 30 \\
\text { (more than } 75 \% \text { ) }\end{array}$ & Excellent (highly recommended) \\
\hline
\end{tabular}


For the overall rating of the language-learning website, the evaluator should count out the number of $\mathbf{X}$ entries on the YES column bearing in mind that the three evaluation dimensions (technical, contextual pedagogical characteristics and the ones related to the Communicative Approach principles) comprise a total of 49 evaluation descriptors. The following chart displays in detail the possible results:

\begin{tabular}{|c|c|}
\hline $\begin{array}{c}\text { Number of X entries in the "Yes" column } \\
\text { (Overall evaluation) }\end{array}$ & Degree of qualification \\
\hline $\begin{array}{c}\text { Between } 1 \text { and } 12 \\
\text { (Between } 1 \% \text { and } 25 \%)\end{array}$ & Poor (Not appropriate) \\
\hline $\begin{array}{c}\text { Between } 13 \text { and } 24 \\
\text { (Between } 26 \% \text { and } 50 \%)\end{array}$ & Suitable (acceptable with reservations) \\
\hline $\begin{array}{c}\text { Between } 25 \text { and } 36 \\
\text { (Between } 51 \% \text { and } 75 \%)\end{array}$ & Good (appropriate for use) \\
\hline $\begin{array}{c}\text { Between } 37 \text { and } 49 \\
\text { (more than } 75 \%)\end{array}$ & Excellent (highly recommended) \\
\hline
\end{tabular}

\section{Biographies}

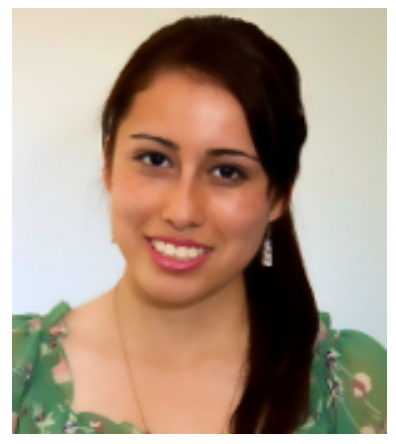

Mg. Sthephanny Moncada Linares is an English and research professor at the School of Education, La Gran Colombia University (Bogotá, Colombia). She holds a B.A. in Spanish, English and French from La Salle University and a M.A. in Applied Linguistics of Spanish as a Foreign Language from La Pontificia Universidad Javeriana. During the school year 2012-2013, she served as a Spanish Assistant as a Foreign Language (Amity Scholar) at University of Wisconsin-La Crosse (United States). Last year, 2015, she participated as a speaker in the Eighth edition of the International Conference ICT for foreign learning at Florence, Italy.

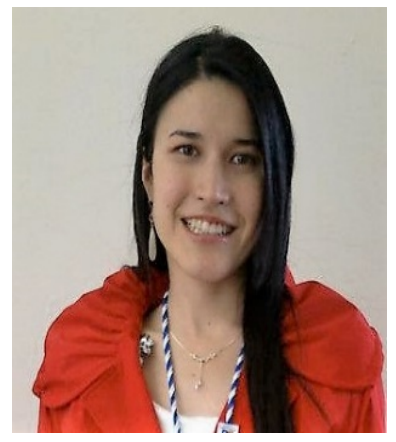

Mg. Andrea Carolina Díaz Romero is a high school English teacher at Cristo Rey Bogotá School. Carolina received a Bachelor of Arts Degree in Spanish, English and French in 2012 from La Salle University and a Master of Arts Degree in Applied Linguistics to the Spanish as a Foreign Language in 2015. Recently, she participated as a speaker in the Eighth edition of the International Conference ICT for foreign learning at Florence, Italy. She has worked as an English teacher for 5 years. 